\title{
The Long and Short of the Canada-U.S. Free Trade Agreement
}

\author{
Daniel Trefler ${ }^{*}$. \\ University of Toronto \\ Canadian Institute for Advanced Research (CIAR) \\ and \\ National Bureau of Economic Research (NBER)
}

$\mathrm{EI} / 41$

January 2006
The Toyota Centre

Suntory and Toyota International Centres for Economics and Related Disciplines

London School of Economics and Political Science Houghton Street

London WC2A $2 \mathrm{AE}$

Tel: (020) 79556674

\footnotetext{
* Joseph L. Rotman School of Management and Department of Economics, University of Toronto, 105 St. George Street, Toronto, ON M5S 3E6. Telephone: (416) 946-7945. E-mail: trefler@chass.utoronto.ca .

$\dagger I$ have benefited from the research assistance of Yijun Jiang, Huiwen Lai, Runjuan Liu, and Susan Zhu. Michael Baker, Erwin Diewert, Peter Dungan, Gerry Helleiner, Pravin Krishna, Aloysius Siow and members of the Canadian Institute for Advanced Research (CIAR) provided key comments that dramatically improved the paper. Much more than is usually the case, this paper was dramatically overhauled in response to the creative input from two anonymous referees. Many members of Statistics Canada provided advice on data issues including Richard Barnabé (Standards Division), Jocelyne Elibani (International Trade Division), Richard Landry (Investment and Capital Stock Division), Jean-Pierre Maynard (Productivity Division), Bruno Pepin (Industry Division), and Bob Traversy (Industry Division). I am especially grateful to John Baldwin (Director, Micro-Economic Studies and Analysis Division) for making available the plant-level data. Alla Lileeva was kind enough to analyse the plant-level data in Ottawa. Research support from the Social Sciences and Humanities Research Council of Canada (SSHRC) is gratefully acknowledged. Views expressed in this paper do not necessarily reflect those of Statistics Canada or SSHRC.
} 


\begin{abstract}
The Canada-U.S. Free Trade Agreement (FTA) provides a unique window onto the effects of a reciprocal trade agreement on an industrialized economy (Canada). For industries that experienced the deepest Canadian tariff cuts, employment fell by 12 percent and labour productivity rose by 15 percent as low-productivity plants contracted. For industries that received the largest U.S. tariff cuts, there were no employment gains, but plant-level labour productivity soared by 14 percent. These results highlight the conflict between those who bore the short-run adjustment costs (displaced workers and struggling plants) and those who are garnering the long-run gains (consumers and efficient plants). Finally, a simple welfare analysis provides evidence of aggregate welfare gains.
\end{abstract}

(C) The author. All rights reserved. Short sections of text, not to exceed two paragraphs, may be quoted without explicit permission provided that full credit, including $\mathbb{C}$ notice, is given to the source 
The central tenet of international economics is that free trade is welfare improving. We express our conviction about free trade in our textbooks and we sell it to our politicians. Yet the fact of the matter is that we have one heck of a time explaining these benefits to the larger public, a public gripped by Free Trade Fatigue.

Why is the message of professional economists not more persuasive? To my mind there are two reasons. First, in examining trade liberalization we treat short-run transition costs and long-run efficiency gains as entirely separate areas of inquiry. On the one hand are those who study the long-run productivity benefits of free trade policies e.g., Tybout et al. (1991), Levinsohn (1993), Harrison (1994), Tybout and Westbrook (1995), Krishna and Mitra (1998), Head and Ries (1999b), and Pavcnik (2002). On the other hand are those who study the impacts of freer trade on short-run worker displacement and earnings e.g., Gaston and Trefler (1994, 1995), Revenga (1997), Levinsohn (1999), Beaulieu (2000), and Krishna et al. (2001). Only Currie and Harrison's (1997) study of Morocco examines both labour market outcomes and productivity. In assessing free trade policies there is clearly a bias introduced when looking only at the long-run benefits or only at the short-run costs. Nowhere is this more apparent than for the Canadian experience with the Canada-U.S. Free Trade Agreement (FTA) and its extension to Mexico. The FTA triggered on-going and heated debates about freer trade. This heat was generated by the conflict between those who bore the short run adjustment costs (displaced workers and stakeholders of closed plants) and those who garnered the long run efficiency gains (stakeholders of competitive plants and users of final and intermediate goods).

There is another reason why the free trade message is not more persuasive. While case- 
study evidence abounds about efficiency gains from liberalization (e.g., Krueger 1997), solid econometric evidence for industrialized countries remains scarce. When I teach my students about the effects of free trade on productivity I turn to high-quality studies for Chile (Tybout et al. 1991; Pavcnik 2002), Turkey (Levinsohn 1993), Cote d'Ivoire (Harrison 1994), Mexico (Tybout and Westbrook 1995), and India (Krishna and Mitra 1998) among others. Even though I find these studies compelling, I wonder whether they can be expected to persuade policy makers and voters in industrialized countries such as Canada and the United States. What is needed is at least some research focussing on industrialized countries.

The Canada-U.S. Free Trade Agreement offers several advantages for assessing the shortrun costs and long-run benefits of trade liberalization in an industrialized country. First, the FTA policy experiment is clearly defined. In developing countries, trade liberalization is typically part of a larger package of market reforms, making it difficult to isolate the role of trade policy. Further, the market reforms themselves are often initiated in response to major macroeconomic disturbances. Macroeconomic shocks, market reforms, and trade liberalization are confounded. Indeed, Helleiner (1994, page 28) uses this fact to argue that "Empirical research on the relationship between total factor productivity (TFP) growth and ... the trade regime has been inconclusive." His view is widely shared e.g., Harrison and Hanson (1999) and Rodriguez and Rodrik (1999). In contrast, the FTA was not implemented as part of a larger package of reforms or as a response to a macroeconomic crisis. Second, as Harrison and Revenga (1995, page 1) note, "Trade policy is almost never measured using the most obvious indicators - such as tariffs." Tybout (2000) echoes this criticism. My study of the FTA is particularly careful about constructing pure policy-mandated tariff measures. 
Third, the FTA is not just about import-liberalizing policies. It is a reciprocal agreement that includes export-liberalizing policies as well. It should therefore be expected to induce a pronounced general equilibrium relocation of resources out of import-competing sectors and into export-oriented sectors. I will examine these FTA effects on a large number of Canadian plant and industry outcomes. At the plant and industry levels the outcomes include employment and earnings of both production and non-production workers, skill upgrading, earnings inequality, hours of work, plant size, and labour productivity. At the industry level the outcomes include the number of plants, investment in human capital, imports, exports, trade diversion, and intra-industry trade.

Fourth, the FTA is a preferential trading arrangement. Such arrangements need not be welfare improving. I will examine the two conditions usually put forward as sufficient at least informally - for welfare gains. These are that trade creation must dominate trade diversion and that import prices must not rise (Krishna 2003; Panagariya 2000). Both conditions are satisfied.

The backdrop of the FTA - an industrialized country, a clean policy experiment, the direct policy lever of tariffs, general equilibrium reciprocity effects, and the long list of outcomes including employment, productivity and prices - will be my basis for a rigourous and detailed examination of the short-run costs and long-run benefits of trade liberalization.

The FTA has been the subject of several studies since its implementation on January 1, 1989. Gaston and Trefler (1997) found that the FTA had no effect on earnings and only a modest effect on employment. Beaulieu (2000) found that the employment effect was primarily driven by modest non-production worker employment losses. Claussing (2001) 
found evidence that the FTA raised U.S. imports from Canada (trade creation), but did not divert U.S. imports away from other U.S. trading partners. The most intriguing FTA study is by Head and Ries (1999b). They found that the FTA had little net effect on industry-level average output per plant (which they take as a proxy for scale) and a puzzling effect on Canadian plant exit (exit was induced by falling Canadian tariffs and by falling U.S. tariffs). Unfortunately, none of these papers use plant-level data. Further, I will argue below that at least some of these papers (including my own), suffer specification issues that substantively mar the inferences drawn about the effects of the Canada-U.S. Free Trade Agreement.

\section{The FTA Tariff Cuts: Too Small to Matter?}

This paper deals with the impact of FTA-mandated tariff cuts. The top panel of figure 1 plots Canada's average manufacturing tariff against the United States (solid line) and Canada's average manufacturing tariff against the rest of the world (dashed line). The bottom panel plots the corresponding U.S. tariffs against Canada (solid line) and the rest of the world (dashed line). In 1988, the average Canadian tariff rate against the United States was 8.1 percent. The corresponding effective tariff rate was 16 percent. ${ }^{1}$ Perhaps most importantly, tariffs in excess of 10 percent sheltered one in four Canadian industries. Given that these industries were almost all characterized by low wages, low capital-labour ratios, and low profit margins, the 1988 tariff wall was indeed high. Similar comments apply to the U.S. tariff against Canada, albeit with less force since the average 1988 U.S. tariff

\footnotetext{
${ }^{1}$ Both the nominal and effective tariff rates were aggregated up from the 4-digit SIC level using Canadian production weights. The standard formula used to calculate the effective rate of protection appears in Trefler (2001, page 39). Details about construction of the tariff series appear in Appendix A.
} 
was 4 percent.

That one in four Canadian industries had tariffs in excess of 10 percent depends crucially on the level of aggregation. I am working with 4-digit Canadian SIC data (213 industries). If one aggregates up even to 3-digit data (105 industries), almost no industries had 1988 tariffs in excess of 10 percent. This is important because studies of trade liberalization typically do not work with comparably disaggregated tariff data. For example, papers by Tybout et al. (1991), Levinsohn (1993), Harrison (1994), Tybout and Westbrook (1995), Gaston and Trefler (1997), Krishna and Mitra (1998), and Beaulieu (2000) are never at a finer level of aggregation than 3-digit ISIC with its 28 manufacturing sectors.

The core feature of the FTA is that it reduced tariffs between Canada and the United States without reducing tariffs against the rest of the world. Graphically, the FTA placed a gap between the dashed and solid lines of figure 1. Letting $i$ index industries and $t$ index years, my measures of the FTA policy levers will be

$\tau_{i t}^{C A}$ : the FTA-mandated Canadian tariff concessions granted to the United States. In terms of the top panel of figure 1 , this is the solid line minus the dashed line.

$\tau_{i t}^{U S}$ : the FTA-mandated U.S. tariff concessions granted to Canada. In terms of the bottom panel of figure 1 , this is the solid line minus the dashed line.

$\tau_{i t}^{C A}$ and $\tau_{i t}^{U S}$ capture the core textual aspects of the FTA. ${ }^{2}$

\footnotetext{
${ }^{2}$ Given that tariffs are positively correlated with effective tariffs and nontariff barriers to trade (NTBs), the coefficients on $\tau_{i t}^{C A}$ and $\tau_{i t}^{U S}$ will capture the effects of FTA-mandated reductions in tariffs, effective tariffs, and nontariff barriers. This is exactly what I want: When analysing tariff concessions I am actually capturing a broader set of FTA trade-liberalizing policies.
} 


\section{Econometric Strategy}

In this section, I lay out econometric strategies for analysing the plant- and industry-level data. I begin with the latter. Let $i$ index industries, let $t$ index years, and let $Y_{i t}$ be a Canadian outcome of interest such as employment or productivity. The FTA mandates that tariffs be reduced once a year on January 1, starting in 1989. I have data for the FTA period 1989-96. In what follows I will define the pre-FTA period as the years 1980-86. As will be shown in detail, this choice is useful for dealing with business fluctuations. Let $\Delta y_{i s}$ be the average annual log change in $Y_{i t}$ over period $s$ where $s=1$ indexes the FTA period and $s=0$ indexes the pre-FTA period. That is,

$$
\Delta y_{i s} \equiv\left\{\begin{array}{cc}
\left(\ln Y_{i, 1996}-\ln Y_{i, 1988}\right) /(1996-1988) & \text { for } s=1 \\
\left(\ln Y_{i, 1986}-\ln Y_{i, 1980}\right) /(1986-1980) & \text { for } s=0
\end{array}\right.
$$

The FTA period changes use 1988 data because I am interested in comparing the FTAperiod outcome $Y_{i, 1996}$ with its baseline level i.e., with its level before the first round of tariff reductions on January $1,1989 .{ }^{3}$ For $k=C A$ and $k=U S$, define

$$
\Delta \tau_{i 1}^{k} \equiv\left(\tau_{i, 1996}^{k}-\tau_{i, 1988}^{k}\right) /(1996-1988) .
$$

$\Delta \tau_{i 1}^{C A}$ measures the change in the FTA-mandated tariff concessions extended by Canada to the United States. Likewise, $\Delta \tau_{i 1}^{U S}$ measures the change in the FTA-mandated tariff

\footnotetext{
${ }^{3}$ Since this may cause confusion, consider by analogy a cholesterol-reducing drug trial in which the drug is given once a year on January 1 (starting in 1989) and the patient's cholesterol level $Y_{i t}$ is measured once a year on December 31 (starting in 1988). To measure the long term effects of the drug one looks at $Y_{i, 1996}-Y_{i, 1988}$ rather than $Y_{i, 1996}-Y_{i, 1989}$ because $Y_{i, 1988}$ describes the patient cholesterol baseline without drugs. The same logic holds for the 'drug of free trade.' The FTA mandates that tariffs be reduced once a year on January 1 (starting in 1989) and the plants are surveyed once a year as closely as possible to December 31. Therefore, the appropriate baseline is $Y_{i, 1988}$.
} 
concessions extended by the United States to Canada.

What of pre-FTA period tariff concessions, which I denote by $\Delta \tau_{i 0}^{k}$ ? Except for the 1965 Canada-U.S. Auto Pact, all tariff rates were extended on a Most Favoured Nation (MFN) basis prior to 1988 . Thus, define $\Delta \tau_{i 0}^{k} \equiv\left(\tau_{i, 1986}^{k}-\tau_{i, 1980}^{k}\right) /(1986-1980)$ when industry $i$ is in the automotive sector and $\Delta \tau_{i 0}^{k}=0$ otherwise. As will be shown, setting $\Delta \tau_{i 0}^{k}=0$ for all $i$ or omitting the automotive sector entirely from the analysis makes no difference to the results. Additional details about $\Delta \tau_{i 1}^{k}$, including a list of industries with large absolute values of $\Delta \tau_{i 1}^{C A}$ and $\Delta \tau_{i 1}^{U S}$, appear in appendix A.

I am interested in a regression model explaining the impact of the FTA-mandated tariff concessions on a variety of industry outcomes:

$$
\Delta y_{i s}=\theta_{s}+\beta^{C A} \Delta \tau_{i s}^{C A}+\beta^{U S} \Delta \tau_{i s}^{U S}+\varepsilon_{i s}, \quad s=0,1
$$

where $\theta_{s}$ is a period fixed effect. There is an obvious problem with estimating equation (3). I have no deeply satisfying way of controlling for the lack of randomization in the tariff concessions. I must thus take particular care to control both for the endogeneity of tariffs and for sources of industry-level heterogeneity that might contaminate the estimates of $\beta^{C A}$ and $\beta^{U S}$. I turn to this task now.

\subsection{The Secular Growth Control}

For political economy reasons, one might expect declining industries to have high tariffs and hence deep FTA tariff concessions e.g., Trefler (1993). To prevent mistakenly attributing secular growth trends to the FTA tariff concessions, I introduce a growth fixed effect $\alpha_{i}$ into equation (3): 


$$
\Delta y_{i s}=\alpha_{i}+\theta_{s}+\beta^{C A} \Delta \tau_{i s}^{C A}+\beta^{U S} \Delta \tau_{i s}^{U S}+\varepsilon_{i s}, \quad s=0,1
$$

As a result, $\beta^{C A}$ and $\beta^{U S}$ only pick up FTA impacts on industry growth that are departures from industry trend growth.

\subsection{Industry-Specific Shocks}

A number of Canadian industries experienced reversals of fortune in the sense that employment growth in the pre-FTA and FTA periods had opposite signs. For these industries similar reversals also appeared in their U.S. counterparts. This is indicative of industryspecific demand and supply shocks. If these reversals of fortune are a characteristic of highly protected industries, the reversals might contaminate the estimates of $\beta^{C A}$ and $\beta^{U S}$. Controlling for reversals of fortune begins with the observation that many industry-specific shocks that appeared in Canada also appeared in Canada's major trading partners. For example, higher oil prices effected the petroleum industry in Canada and all its major trading partners. I have industry-level data for Canada's 3 largest trading partners: the United States, Japan, and the United Kingdom. I use these data to control for industry-specific shocks.

More formally, let $\Delta y_{i s}^{j}$ be data on $\Delta y_{i s}$ for economy $j$ e.g., if $\Delta y_{i s}$ is Canadian employment growth then $\Delta y_{i s}^{j}$ is country $j$ 's employment growth. I control for industry-specific shocks by including $\Delta y_{i s}^{j}$ in equation (4). Note that it is unlikely that $\Delta y_{i s}^{j}$ is exogenous, especially for $j=U S$, so I will have to employ instrumental variables (IV) techniques. Finally, for expositional ease I will refer to $\Delta y_{i s}^{j}$ as the 'U.S. control' and simply write $\Delta y_{i s}^{U S}$. 


\subsection{The Business Conditions Control}

A key issue for examining the FTA is the treatment of the early 1990s recession. Figure 2 plots GDP in year $t\left(g d p_{t}\right)$ for Canadian manufacturing. The data are in logs relative to a 1980 base i.e., $\ln \left(g d p_{t} / g d p_{1980}\right)$. The FTA period recession stands out. This is a problem if the industries that experienced the deepest tariff concessions share a common sensitivity to changes in business conditions. General business conditions can be introduced into equation (4) by including a regressor $\Delta b_{i s}$ that captures how movements in GDP and the real exchange

rate affect industry $i$. I will explain how $\Delta b_{i s}$ is constructed shortly. Introducing $\Delta b_{i s}$ and $\Delta y_{i s}^{U S}$ into equation (4) yields

$$
\Delta y_{i s}=\alpha_{i}+\theta_{s}+\beta^{C A} \Delta \tau_{i s}^{C A}+\beta^{U S} \Delta \tau_{i s}^{U S}+\gamma \Delta y_{i s}^{U S}+\delta \Delta b_{i s}+\varepsilon_{i s}, \quad s=0,1
$$

\subsection{Estimation}

Differencing (5) across periods yields my difference-of-differences baseline specification:

$$
\begin{aligned}
\left(\Delta y_{i 1}-\Delta y_{i 0}\right)=\theta & +\beta^{C A}\left(\Delta \tau_{i 1}^{C A}-\Delta \tau_{i 0}^{C A}\right)+\beta^{U S}\left(\Delta \tau_{i 1}^{U S}-\Delta \tau_{i 0}^{U S}\right) \\
& +\gamma\left(\Delta y_{i 1}^{U S}-\Delta y_{i 0}^{U S}\right)+\delta\left(\Delta b_{i 1}-\Delta b_{i 0}\right)+v_{i}
\end{aligned}
$$

where $\theta \equiv \theta_{1}-\theta_{0}$. This specification controls for secular industry trends (by differencing out the $\alpha_{i}$ ), industry-specific demand and supply shocks (the $\Delta y_{i s}^{U S}$ ), and industry-specific business condition effects (the $\Delta b_{i s}$ ). Clearly, I will have to use an IV estimator to deal with the endogeneity of the tariff concessions and $\Delta y_{i 1}^{U S}-\Delta y_{i 0}^{U S}$. 
It is important to note that the use of long double-differencing means that I need not worry about dynamic panel estimation problems (Arellano and Honoré, 2001). This is important because all previous FTA studies have used annual data without any correction for autocorrelation i.e., Gaston and Trefler (1997), Head and Ries (1999a,b), Beaulieu (2000), and Claussing (2001). Yet the fact is that employment and output display strong autocorrelation at lags of up to 3 years. For example, Canadian employment displays significant 3-year autocorrelation in 31 percent of all industries and 1-year autocorrelation in an overwhelming 77 percent of all industries. Thus, the estimators used in all previous studies of the FTA (including my own) are inconsistent and yield standard errors that are too small.

\subsection{Plant-Level Data}

Letting $k$ index plants, my baseline plant-level specification is

$$
\begin{aligned}
\left(\Delta y_{i k 1}-\Delta y_{i k 0}\right)=\theta & +\beta^{C A}\left(\Delta \tau_{i 1}^{C A}-\Delta \tau_{i 0}^{C A}\right)+\beta^{U S}\left(\Delta \tau_{i 1}^{U S}-\Delta \tau_{i 0}^{U S}\right)+\phi x_{i k, 1980} \\
& +\gamma\left(\Delta y_{i 1}^{U S}-\Delta y_{i 0}^{U S}\right)+\delta\left(\Delta b_{i 1}-\Delta b_{i 0}\right)+v_{i k}
\end{aligned}
$$

where $\Delta y_{i k s}$ is the change in the outcome of interest for plant $k$ in industry $i$ in period $s$ and $x_{i k, 1980}$ is a vector of plant characteristics that includes the log of 1980 employment, the log of 1980 earnings per worker, the log of 1980 labour productivity, and the log of plant age. Since the plant data only go back to 1973, I also include a dummy for whether the plant was older than 7 years of age in 1980 . There are 3,801 plants in the sample. ${ }^{4}$

\footnotetext{
${ }^{4}$ I am indebted to Alla Lileeva for running these regressions and for sharing her experience as to which plant-level controls to use. Without her, the plant-level analysis would not have been possible.
} 
There are two selection issues that require attention. First, equation (7) only makes use of plants that were in existence in 1980, 1986, 1988, and 1996. Obviously these 'continuing' plants are not representative of all plants. Unfortunately, I have not been able to make even simple corrections for entry and exit because the database available to me cannot be used in any simple way to track entry and exit. (Unlike the U.S. longitudinal plant database, the Canadian database has not attracted as many resources for data 'cleaning' and data access.) Second, I will be working with what are known as 'long-form' plants, that is, plants that fill out a detailed survey. In 1988, long-form plants were 2.2 times larger than 'short-form' plants. Thus, my plant-level results must be understood as dealing with larger plants. This said, appendix E provides some evidence that my results apply to small plants as well. ${ }^{5}$

\section{The Data}

Canadian data are from the Canadian Annual Survey of Manufactures (ASM), the Canadian Labour Force Survey, the International Trade Division, the Input-Output Division, the Prices Division, and the Standards Division (for commodity and industry concordances). Almost all the data used involved special tabulations by Statistics Canada. Most of the U.S. data through 1994 are from the NBER Manufacturing Productivity Database (Bartelsman and Gray, 1996) and Feenstra (1996). I updated these sources to 1996. As discussed in Trefler (2001, page 11), I have been especially careful to build a Canada-U.S. converter that steps down from over 1,000 U.S. products to 213 Canadian industries.

\footnotetext{
${ }^{5}$ One final thought on the estimating equation. This paper is unabashedly a reduced-form exercise that allows the inferences to be driven more by the data than by a highly structured model. This has obvious advantages, but it also has a cost. A more structured approach, as in Head and Ries (2001) or Lai and Trefler (2002), muzzles the data, but allows for a clearer interpretation of the coefficients and for a richer treatment of general equilibrium feedbacks.
} 


\section{Empirical Results: Employment}

Table 1 reports estimates of equations (6) and (7) for the case where the dependent variable is employment growth. The table includes a large number of specifications in order to show that the estimates of $\beta^{C A}$ and $\beta^{U S}$ are not particularly sensitive to the choice of specification. Row 1 is my industry-level baseline specification. It uses ordinary least squares (OLS) and includes all 4 regressors. I will explain coefficient magnitudes shortly, but for now treat $\widehat{\beta}^{C A}$ and $\widehat{\beta}^{U S}$ as the log-point changes in employment associated with the FTA. For example, the Canadian tariff concessions led to a -.12 log-point change in employment $(t=-2.35)$.

The first specification issue handled by table 1 deals with the sensitivity of $\widehat{\beta}^{C A}$ and $\widehat{\beta}^{U S}$ to the way in which the business conditions variable $\Delta b_{i s}$ is constructed. In order to explain how $\Delta b_{i s}$ is constructed, define $z_{t} \equiv\left(\ln g d p_{t}, \ln r e r_{t}\right)$ where $r e r_{t}$ is the real exchange rate and let $\Delta_{1}$ be the annual difference operator so that $\Delta_{1} z_{t}=z_{t}-z_{t-1}$ and $\Delta_{1} y_{i t}=y_{i t}-y_{i, t-1}$. To construct $\Delta b_{i s}$, I first regressed $\Delta_{1} y_{i t}$ on $\left(\Delta_{1} z_{t}, \ldots, \Delta_{1} z_{t-J}\right)$ for some lag length $J$. This is a time-series regression that was estimated separately for each $i$. The regression generates an industry-specific prediction $\widehat{\Delta_{1}} y_{i t}$ of the effect of current and past business conditions on current annual employment growth. Second, note from equation (1) that $\Delta y_{i 1}$ can be written as $\sum_{t=1989}^{1996} \Delta_{1} y_{i t} / 8$. This motivates the definition of $\Delta b_{i 1}$ as $\Delta b_{i 1} \equiv \sum_{t=1989}^{1996} \widehat{\Delta_{1}} y_{i t} / 8$. $\Delta b_{i 1}$ is just an industry-specific prediction of the effect of business conditions on FTA-period employment growth. For the pre-FTA period I use $\Delta b_{i 0} \equiv \Sigma_{t=1981}^{1986} \widehat{\Delta_{1} y_{i t}} / 6$. Note that there is a different $\Delta b_{i s}$ for each outcome. For example, when $\Delta y_{i s}$ is earnings growth then $\Delta b_{i s}$ is the portion of industry $i$ earnings growth driven by movements in GDP and the real exchange rate. See appendix C for further details. 
Row 1 of table 1 uses my baseline specification of $\Delta b_{i s}$ in which the lag length is $J=2$. I chose $J=2$ because the industry-specific autocorrelation functions only vanish at longer lags. Row 2 of table 1 , which uses $J=0$, illustrates that $\widehat{\beta}^{C A}$ and $\widehat{\beta}^{U S}$ are not sensitive to the choice of lag length. Row 3 uses $J=2$, but drops the real exchange rate $\left(r e r_{t}\right)$ from $z_{t}$. This does not dramatically alter the estimates either. In fact, as row 4 shows, the estimates rise only slightly when $\Delta b_{i 1}-\Delta b_{i 0}$ is omitted from the baseline specification. This requires some explanation as it might be misinterpreted to mean that business conditions are playing only a minor role.

Returning to figure 2, the $1980-86$ and $1988-96$ periods are very similar in terms of business conditions. Each began a year before the peak, each entered a deep recession in the third year, and each ended in the midst of a prolonged expansion. Further, my decision to end the pre-FTA period in 1986 ensures that the two periods are similar as judged by GDP growth over the period and by the number of years into the expansion. That is, I have purposely chosen the pre-FTA period so that, after double-differencing, my estimating equations have a built-in, implicit control for business conditions. This explains why omitting $\Delta b_{i 1}-\Delta b_{i 0}$ does not dramatically alter the results. Also note that the results are similar with the pre-FTA period defined as 1980-88 or the FTA period defined as 1988-94. See appendix table A2.

Finally, $\Delta b_{i 1}-\Delta b_{i 0}$ is a generated regressor which means that some care is needed to ensure correct standard errors. Fortunately, it is straightforward to show that my reported OLS standard errors come from the same distribution as the asymptotically 'true' (i.e., $\sqrt{N}$ limiting) distribution. This can be shown by verifying that condition (6.3) on page 116 of 
Wooldridge (2002) is satisfied. Further specification tests are discussed in appendix C.

Consider now the U.S. control variable $\Delta y_{i 1}^{U S}-\Delta y_{i 0}^{U S}$. Its coefficient is positive for all results reported in this paper. This is to be expected if it is picking up demand and supply shocks that are common to both U.S. and Canadian industries. Row 5 replaces $\Delta y_{i 1}^{U S}-\Delta y_{i 0}^{U S}$ with $\left(\Delta y_{i 1}^{J a p a n}+\Delta y_{i 1}^{U K}\right) / 2-\left(\Delta y_{i 0}^{\text {Japan }}+\Delta y_{i 0}^{U K}\right) / 2$. Comparison of row 5 with row 1 reveals that this makes little difference to $\widehat{\beta}^{C A}$ or $\widehat{\beta}^{U S}$. Row 6 shows that the omission of the U.S. control also makes little difference. Clearly, $\widehat{\beta}^{C A}$ and $\widehat{\beta}^{U S}$ are not sensitive to how the U.S. control is modelled. This conclusion will continue to hold when I endogenize the U.S. control in row $13 .^{6}$

Row 7 shows that omission of both the U.S. control and the business conditions control has no effect on $\widehat{\beta}^{U S}$, but does raise $\widehat{\beta}^{C A}$ from -0.12 to -0.17 . I conclude from rows $1-7$ that my row 1 baseline estimates are not sensitive to the exact treatment of industry-specific shocks (the U.S. control) or the business conditions control provided that at least one of them is included in the specification. This conclusion holds true for all the statistically significant estimates reported in this paper.

Rows 8 and 9 examine the role of particular observations. As appendix table A1 shows, the Brewery and Shipbuilding industries have unusually large Canadian tariff concessions and are thus potentially influential observations. In row 8 , I delete these observations. This

\footnotetext{
${ }^{6}$ Throughout this paper I will use U.S. data rather than Japan-U.K. data. The disadvantage of using $\Delta y_{i s}^{U S}$ is that the Canadian tariff concessions likely raised U.S. employment at the expense of Canadian employment. However, if this were an important feature of the data then I would expect the correlation between $\Delta y_{i 1}^{U S}$ and $\Delta y_{i 1}$ to be negative (in fact it is a strongly positive 0.50) and the coefficient on $\left(\Delta y_{i 1}^{U S}-\right.$ $\left.\Delta y_{i 0}^{U S}\right)$ to be negative (in fact, it also is strongly positive). The disadvantage of $\left(\Delta y_{i s}^{\text {Japan }}+\Delta y_{i s}^{U K}\right) / 2$ is that these data are only available at the 3 -digit ISIC level (28 industries). This means that I must concord data on 28 industries into data on 213 4-digit Canadian SIC industries. The result is noisy data. I thus prefer using U.S. data. Clearly, however, it does not matter which I use. Finally, the Japanese and U.K. data are from the UNIDO database.
} 
slightly raises $\widehat{\beta}^{C A}$. In row 9 , I delete the 9 industries in the automotive sector. This raises $\widehat{\beta}^{U S}$, but not significantly.

Row 10 is my baseline plant-level specification. It includes the plant-level controls i.e., plant age and the 1980 values of the log of employment, the log of earnings, and the log of labour productivity. Notice that the plant-level estimate of $\beta^{C A}$ and $\beta^{U S}$ are almost identical to the industry-level estimates of row 1. This suggests that, at least for employment, the industry-level regressions are capturing within-plant effects rather than between-plant effects. $^{7}$

The U.S. tariff concessions had no effect on employment at the plant level, but modestly reduced employment at the industry level. This means that the U.S. tariff concessions must have forced more labour-intensive plants to contract. My student Alla Lileeva has refined this observation by showing that the plant-level result reflects the effect of pooling across exporters (for which $\beta^{U S}>0$ ) and non-exporters (for which $\beta^{U S}<0$ ). She has linked the Canadian plant-level data to data on the exporter status of the plant. While the match precludes using my difference-of-differences methodology, she has nevertheless been able to show that $\widehat{\beta}^{U S}$ is positive for exporters and hugely negative for non-exporters. Why? The U.S. tariff concessions had the unexpected effect of encouraging Canadian exporters to expand their domestic operations at the expense of Canadian non-exporters. Since the majority of plants are non-exporters, pooling across exporters and non-exporters yields

\footnotetext{
${ }^{7}$ If this is not clear consider the following. Let $x_{i k t}$ be some characteristic of plant $k$ in industry $i$ in year $t$, let $s_{i k t}$ be plant $k$ 's market share and let $x_{i t} \equiv \Sigma_{k} x_{i k t} s_{i k t}$ be the average value of $x_{i k t}$. Using obvious difference notation, $\Delta x_{i t}=\Sigma_{i} \Delta x_{i k t} s_{i k t}+\Sigma_{i} \Delta s_{i k t} x_{i k, t-1}$ i.e., the total industry change can be decomposed into a within-plant change (the first term) and a between-plant or market-share shift change (the second term). The plant level regressions deal with $\Delta x_{i k t}$ and thus capture within-plant changes. The industry-level regressions deal with $\Delta x_{i t}$ and thus capture both within-plant and market-share shift changes.
} 
estimates of $\beta^{U S}$ that are close to 0 .

Returning to the plant-level estimates in table 1, row 11 excludes the plant-level controls. Comparison with row 10 shows that $\widehat{\beta}^{C A}$ or $\widehat{\beta}^{U S}$ are unaffected by the exclusion of the plantlevel controls.

Rows 12-15 report the IV results. A key issue is the identification of variables that satisfy the two requirements of an instrument. The most likely candidates for valid instruments are variables measuring the level of industry characteristics in 1980. For one, these level characteristics are unlikely to be correlated with the residuals because the latter are twicedifferenced. Such difference of differences are far removed from levels. For another, the 1980 characteristics determine the 1980 levels of protection which in turn are correlated with the tariff changes. I therefore use an instrument set that consists of 1980 log values for: (1) Canadian hourly wages, which captures protection for low-wage industries as in Corden's (1974) conservative social welfare function, (2) the level of employment, which captures protection for large industries as in Finger et al.'s (1982) high-track protection for large industries, (3) Canadian imports from the United States, and (4) U.S. imports from Canada. I also include squares and cross-products as well as any exogenous regressors. The first-stage $R^{2}$ s are between 0.30 and 0.40 for almost all the results in this paper.

Row 12 repeats the specification of row 1, but with the two tariff regressors instrumented. $\widehat{\beta}^{C A}$ and $\widehat{\beta}^{U S}$ are now much larger. Also, $\widehat{\beta}^{U S}$ reverses signs, suggesting that the U.S. tariff concessions raised Canadian employment. However, these results do not pass the Hausman test.

The 'OverId/Hausman' column reports $p$-values for over-identification and Hausman 
tests. In row 12, both the over-identification test (0.60) and the Hausman test (0.65) are above 0.01 which indicates that the instruments are valid at the 1 percent level and that endogeneity is rejected at the 1 percent level. Given the poor small-sample properties of IV estimators (Nelson and Startz, 1990), I use the 1 percent cut-off i.e., p-values below 0.01.

Row 13 reports the IV estimates for the case where the U.S. control is instrumented along with the two tariff concessions. Comparing row 13 with row 12, it is clear that endogenizing the U.S. control has no impact on the estimates of $\widehat{\beta}^{C A}$ and $\widehat{\beta}^{U S}$. Further, endogeneity continues to be rejected. ${ }^{8}$

Rows 14 and 15 repeat the IV exercises of rows 12 and 13, respectively, but starting with the plant-level baseline specification of row 10. As with the industry-level results, the $\widehat{\beta}^{C A}$ and $\widehat{\beta}^{U S}$ are much larger, but endogeneity is rejected. Indeed, endogeneity is easily rejected for every plant-level specification reported in this paper. This likely reflects the fact that tariffs, even if endogenous to the industry, are exogenous to the plant.

\section{Coefficient Magnitudes}

I have not yet properly explained the magnitudes of $\widehat{\beta}^{C A}$ and $\widehat{\beta}^{U S}$. Since the distribution of tariff concessions is skewed, it is of interest to know the effect of the Canadian tariff concessions on the most-impacted, import-competing group of industries i.e., on the one-third of industries with the most negative values of $\Delta \tau_{i 1}^{C A}$. This group has $71(=213 / 3)$ industries,

\footnotetext{
${ }^{8}$ As someone who has tried to build a career on the endogeneity of protection (Trefler, 1993), I am surprised by the rejection of endogeneity. To investigate further, I have experimented with a much larger set of instruments drawn from 1980 and 1988 characteristics of Canadian and U.S. industries. I have also experimented with a drastically reduced instrument. None of this makes any difference to the conclusion that endogeneity is rejected. As a result, I will report the industry-level IV results, but downplay them. Interestingly, endogeneity only comes into play when the dependent variable is imports.
} 
tariff concessions ranging from -5 to -33 percent, and an average tariff concession of -10 percent. The industries are listed in appendix table A1. For any industry $i$, the Canadian tariff concessions are estimated to change employment by $\widehat{\beta}^{C A} \Delta \tau_{i 1}^{C A} \log$ points. For the most-impacted, import-competing group as a whole this change is given by $\widehat{\beta}^{C A} \overline{\Delta \tau}_{\cdot 1}^{C A}$ where $\overline{\Delta \tau}_{11}^{C A}$ is a weighted average of the $\Delta \tau_{i 1}^{C A}$ with weights that depend on industry size. (See appendix B for details about the weights.) It is $\widehat{\beta}^{C A} \overline{\Delta \tau}_{\cdot 1}^{C A}$ that is reported in the $\beta^{C A}$ column of all the tables in this paper. From row 1 of table 1, the most-impacted, import-competing group as a whole experienced a 12 percent employment loss.

A similar discussion of coefficient magnitudes applies to the most-impacted, exportoriented group of industries i.e., the one-third of industries (71 industries) with the most negative values of $\Delta \tau_{i 1}^{U S}$. For this group the estimated impact of the U.S. tariff concessions on employment is given by $\widehat{\beta}^{U S} \overline{\Delta \tau}_{\text {.1 }}^{U S}$ where $\overline{\Delta \tau}_{\text {.1 }}^{U S}$ is the weighted average of the $\Delta \tau_{i 1}^{U S}$. $\widehat{\beta}^{U S} \overline{\Delta \tau}_{.1}^{U S}$ is reported in the $\beta^{U S}$ column of all the tables in this paper. From row 1 of table 1, this group experienced a statistically insignificant and non-robust 3 percent employment loss.

The 'Total FTA Impact' columns in this paper present the joint effect of the tariff concessions on manufacturing employment as a whole. This effect is just

$$
T F I \equiv \widehat{\beta}^{C A} \overline{\Delta \tau}_{\cdot 1}^{C A}+\widehat{\beta}^{U S} \overline{\Delta \tau}_{\cdot 1}^{U S}
$$

where $\overline{\Delta \tau}_{\cdot 1}^{C A}$ and $\overline{\Delta \tau}_{\cdot 1}^{U S}$ are now defined as averages across all 213 industries. From the 'TFI' column of row 1 in table 1, the FTA reduced manufacturing employment by 5 percent. This impact is statistically significant and quite similar across all the OLS specifications. It stands in sharp contrast to Gaston and Trefler (1997) who found economically small and 
statistically insignificant effects of the FTA. The difference in conclusions reflects both the better data and the better methodology of the current study.

Employment losses of 5 percent translate into 100,000 lost jobs and strike me as large, not least because only a relatively small number of industries experienced deep tariff concessions. Indeed, most of these lost jobs were concentrated in the most-impacted, import-competing industries. For this group, with its 12 percent job losses, one in eight jobs disappeared. This number points to the very large transition costs of moving out of low-end, heavily protected industries. It reflects the most obvious of the costs associated with trade liberalization.

It is difficult to be sure whether these transition costs were short-run in nature. However, two facts drawn from the most recent seasonally adjusted data suggest that they probably were short run costs. First, the FTA had no long-run effect on the Canadian employment rate which was 62 percent both in April 1988 and April 2002. Second, Canadian manufacturing employment has been more robust than in most OECD countries. For example, between April 1988 and April 2002, manufacturing employment rose by 9.1 percent in Canada, but fell by 12.9 percent in the United States and by 9.7 percent in Japan. This suggests, albeit not conclusively, that the transition costs were short run in the sense that within 10 years the lost employment was made up for by employment gains in other parts of manufacturing.

\section{Labour Productivity}

It would be best to examine productivity using a total factor productivity (TFP) measure. Unfortunately, the Canadian ASM does not record capital stock or investment data. There is thus little alternative but to work with labour productivity. I define labour productivity 
as value added in production activities per hour worked by production workers. ${ }^{9}$ I deflate using 3-digit SIC output deflators. ${ }^{10}$ Table 2 reports the labour productivity results. The table has the exact same format as the table 1 employment results so that I can review it quickly. As in the table 1 , endogeneity is always rejected ${ }^{11}$ and all the industry-level OLS results are similar so that I can focus on the baseline row 1 specification.

From the industry-level OLS results, the Canadian tariff concessions raised labour productivity by 15 percent in the most-impacted, import-competing group of industries $(t=$ 3.11). This translates into an enormous compound annual growth rate of 1.9 percent. The fact that the effect is smaller and statistically insignificant at the plant level (row 10) suggests that much of the productivity gain is coming from market share shifts favouring high productivity plants. Such share shifting would come about from the growth of high-productivity plants and the demise and/or exit of low-productivity plants.

From the plant-level OLS results (row 10), the U.S. tariff concessions raised labour productivity by 14 percent or 1.9 percent annually in the most-impacted, export-oriented group of industries $(t=3.97)$. This labour productivity gain does not appear at the industry level $\left(\widehat{\beta}^{U S}=0.04, t=1.14\right)$ which is likely due to the fact that the U.S. tariff concessions encouraged entry of plants that are less productive by virtue of being young. (On the low

\footnotetext{
${ }^{9}$ Trefler (2001) extensively examined the sensitivity of results to alternative definitions of labour productivity. Appendix D of the current paper shows that the results are not sensitive to redefining labour productivity as total value added (in both production and non-production activities) per worker (both production and non-production workers). This definition does not correct for hours; however, it is useful in that it is directly comparable to the way in which I am forced to define U.S. labour productivity in $\Delta y_{i s}^{U S}$. (The U.S. ASM does not report value added in production activities.)

${ }^{10}$ Appendix D also shows that the results do not change when labour productivity is deflated by the available 2-digit SIC value-added deflators. I am indebted to Alwyn Young for encouraging me to carefully examine the issue of deflators.

${ }^{11}$ The table 2 IV results are based on an instrument set without squares or cross-products because these are rejected by the over-identification tests.
} 
productivity of young plants see Baldwin 1995 for Canada and Bernard and Jensen 1995 for

the United States.) The importance of controlling for plant age can be seen by comparing rows 10 and 11 since the latter excludes the plant age control and has a lower $\widehat{\beta}^{U S} \cdot{ }^{12}$

The last column of table 2 looks at the total FTA impact on all of manufacturing. The plant-level numbers of row 10 indicate that the FTA raised labour productivity in manufacturing by 7.4 percent or by an annual compound growth rate of 0.93 percent $(t=4.92)$. The industry-level numbers are about the same. These numbers, along with the 14-15 percent effects for the most-impacted importers and exporters, are enormous. The idea that an international trade policy could raise labour productivity so dramatically is to my mind remarkable.

\section{Import Prices and Trade Creation/Diversion: Implications for}

\section{Welfare}

Preferential trade arrangements, including the FTA, need not be welfare improving. The literature identifies two conditions which, if satisfied, increase the likelihood of aggregate welfare gains for a representative agent. These are that trade creation 'dominates' trade diversion and that import prices do not rise (Krishna 2003, Panagariya 2000). This section explores these conditions.

\footnotetext{
${ }^{12}$ Another contributing factor to the difference between the $\widehat{\beta}^{U S}$ at the industry and plant levels is that the U.S. tariff concessions encouraged Canadian plants to enter the U.S. market. This must reduce average productivity because new Canadian exporters are less productive than old Canadian exporters (Baldwin and Gu 2001). (This is not true of U.S. exporters. See Bernard and Jensen 1999.) Expansion into the U.S. market therefore increases the market share of lower productivity new exporters, thus reducing the industry-level productivity effect.
} 


\subsection{Trade Creation and Trade Diversion}

Krishna (2003) offers a precise expression for welfare gains in terms of the relative sizes of trade creation and diversion. Let $\Delta \ln m_{i s j}$ be the log change in Canadian imports of industry $i$ in period $s$ from region $j=U S$ or $j=R O W$ (rest of the world). Let $\Delta \tau_{i s j}$ be the corresponding change in the Canadian tariff. Krishna shows that a sufficient condition for welfare gains is

$$
-0.8 \frac{\Delta \ln m_{i 1 U S}}{\Delta \tau_{i 1 U S}}-0.2 \frac{\Delta \ln m_{i 1 R O W}}{\Delta \tau_{i 1 U S}}>0
$$

where 0.8 is the share of Canadian imports originating from the United States. The first term is a utility-relevant measure of trade creation and is positive because $\Delta \ln m_{i 1 U S} / \Delta \tau_{i 1 U S}<0$. The second term is a utility-relevant measure of trade diversion and is likely negative because $\Delta \ln m_{i 1 R O W} / \Delta \tau_{i 1 U S}$ is likely positive. ${ }^{13}$

I examine equation (9) empirically as follows. The first row in table 3 reports estimates of my standard equation (6) using Canadian imports from the United States as the dependent variable. Note that there is no U.S. control in this regression because it makes no sense in an import context. The Canadian tariff concessions raised Canadian imports from the United States by 54 percent. I therefore set $\Delta \ln m_{i 1 U S} / \Delta \tau_{i 1 U S}$ equal to -0.54 . The third row in table 3 reports my estimates of equation (6) using Canadian imports from the rest of the world as the dependent variable. The Canadian tariff concessions lowered Canadian

\footnotetext{
${ }^{13}$ Krishna's analysis looks at a representative consumer in an economy with a single final good. The generalization to many goods is trivial as long as expenditure shares for each good are independent of the tariff e.g., Cobb-Douglas preferences. To derive equation (9), start with equation (10) in Krishna: $\tau_{i U S} \partial m_{i U S} / \partial \tau_{i U S}+\tau_{i R O W} \partial m_{i R O W} / \partial \tau_{i U S}$ where all variables relate to 1988. Since $\tau_{i U S}=\tau_{i R O W}$ in 1988 , this expression can be re-written as $\frac{\tau_{i U S}}{m_{i U S}+m_{i R O W}}\left[\theta_{i U S} \partial \ln m_{i U S} / \partial \tau_{i U S}+\left(1-\theta_{i U S}\right) \partial \ln m_{i R O W} / \partial \tau_{i U S}\right]$

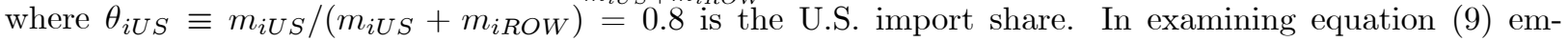
pirically, I ignore the fact that Krishna's $m_{i U S}$ and $m_{i R O W}$ are compensated demands for imports.
} 
imports from the rest of the world by 40 percent. I therefore set $\Delta \ln m_{i 1 R O W} / \Delta \tau_{i 1 U S}$ equal to +0.40 .

Plugging -0.54 and +0.40 into equation (9) yields $-0.8 \times(-0.54)-0.2 \times(0.40)=0.35$ $(t=3.62)$. Since this number is statistically greater than zero, Krishna's (2003) welfare condition is satisfied. This conclusion is robust to the many alternative specifications of tables 1-2. Thus, FTA trade creation dominated FTA trade diversion enough to ensure that the FTA improved aggregate welfare.

\subsection{Prices}

A preferential trading agreement will not likely be welfare improving if it raises prices (Panagariya 2000). Clearly the FTA is unlikely to have raised import prices - this would require either some unusual change in the strategic interactions between firms or a rise in tariffs against non-FTA trading partners. More likely the FTA reduced import prices by allowing U.S. producers to send larger quantities per shipment, thus spreading fixed shipping costs over a larger number of units. Fixed costs of shipping are sufficiently large that reducing them has been a key focus of Canadian public policy. ${ }^{14}$ Surprisingly, there exists very little econometric work on the effects of trade liberalization on import prices. Huber (1971) is a rare exception.

To investigate, I examine the relationship between tariff cuts and changes in import unit values. Both these variables are available at the 10-digit Harmonized System (HS10) level. While unit values are difficult to interpret as prices, the hope is that at this detailed level of disaggregation, changes in unit values over the FTA period reflect changes in prices. Note

\footnotetext{
${ }^{14}$ See the C.D. Howe Border Papers series for reviews of the public policy discussions.
} 
that I am looking only at unit-value changes within an HS10 item. This is very different from and less problematic than the typical use made of unit values. Typically, researchers draw conclusions from the fact that one HS10 item has a higher unit value level than another e.g., Schott (2001). Since unit values are based on actual payments net of import duties, freight, insurance, and other charges, I will interpret changes in unit values as changes in producer prices.

Canadian trade data was first collected in the HS system is $1988 .{ }^{15}$ Let $\Delta \tau_{i 1 j}$ be the FTA period change in Canada's tariff against country $j$ for HS10 product $i$. Let $\Delta \ln p_{i 1 j}$ be the corresponding log import price change. Since I do not have pre-FTA data on import price changes at the HS10 level $\left(\Delta \ln p_{i 0 j}\right)$, I cannot estimate my standard equation (6) with $\Delta \ln p_{i 1 U S}-\Delta \ln p_{i 0 U S}$ as the dependent variable. However, if the FTA had never been implemented one expects $\Delta \ln p_{i 1 U S}$ to have evolved in the same way that Canada's import prices from other advanced economies evolved. I thus estimate

$$
\Delta \ln p_{i 1 U S}-\Delta \ln p_{i 1 O E C D}=\alpha+\beta^{C A}\left(\Delta \tau_{i 1 U S}-\Delta \tau_{i 1 O E C D}\right)+\varepsilon_{i}
$$

where $\Delta \ln p_{i 1 O E C D}$ is the simple average of the $\Delta \ln p_{i 1 j}$ for the United Kingdom, Germany, France, and Japan. Likewise for $\Delta \tau_{i 1 O E C D}$.

The third block of results in table 3 reports the estimates. The OLS estimate indicates that the FTA did not raise import prices $\left(\widehat{\beta}^{C A}=-0.004\right)$. There is modest evidence of endogeneity at the 3 percent level and the IV estimates indicate that the FTA reduced

\footnotetext{
${ }^{15}$ In matching 1988 data with 1996 data I loose 33 percent of the 1988 HS10 items. There is some evidence that the loss is non-random in that the average tariff on the unmatched commodities is 0.5 percentage points lower than on the matched commodities. This reflects the fact that many of the unmatched commodities are in high-tech industries. For example, Intel's introduction of the $486 \mathrm{CPU}$ in 1989 quickly led to the demise of the 386 CPU. (Don't date yourself by admitting you remember this!)
} 
import prices by 7 percent for the most-impacted import-competing products.

One wonders if the HS10 import price changes are so noisy that these results are meaningless. Import prices are defined as import values divided by import quantities so that any noisiness in prices must come from noisiness in quantities. To investigate the role of noise, I re-estimated equation (10) using log import quantity changes as the dependent variable. The fourth block of results in table 3 reports the results. The FTA raised import quantities by 70 percent. The $t$-statistics are huge and the exogeneity of tariffs is strongly rejected just as in Trefler (1993). Thus, noise does not appear to be a problem.

To summarize, two conditions increase the likelihood that a preferential trade arrangement is welfare improving: trade creation must dominate trade diversion and import prices must not rise. Both of these condition are met in the FTA context.

\section{Employment of Production and Non-Production Workers}

I am now in a position to quickly review the results for other outcomes. The data distinguish between workers employed in manufacturing activities and non-manufacturing activities. I will refer to these as production and non-production workers since the distinction broadly follows that used in the U.S. ASM. In particular, non-production workers are more educated and better paid. The top block of results in table 4 reports a limited number of specifications for the employment of production workers. My baseline industry- and plant-level specifications appear in rows 1 and 10, respectively. (Row numbers match those of table 1 so that the reader can always remind herself of the specification details of any row by referring back to the detailed discussion surrounding table 1.) The results indicate that the Canadian 
tariff concessions reduced employment by a large amount, 14 percent using industry-level estimates $(t=-2.44)$ and 9 percent using plant-level estimates $(t=-2.58)$. The effects of the U.S. tariff concessions are less clear. They reduced employment by 7 percent using industry-level estimates, but this is not statistically significant and virtually disappears in the plant-level estimates. The total FTA impact of 8 percent (industry-level) and 4 percent (plant level) are both economically large and statistically significant.

Rows 5, 6, and 12 present alternative specifications. In rows 5 and 6 the business conditions control and the U.S. control are excluded, respectively. This does not affect the $\widehat{\beta}^{C A}$ or $\widehat{\beta}^{U S}$. In row 12 , the industry-level IV results are reported. Endogeneity is rejected $(p=0.99)$. I do not report the plant-level IV results because endogeneity is always strongly rejected at the plant level.

In contrast to the results for production workers, non-production worker employment is estimated to have been unaffected by the U.S. tariff concessions.

Finally, the 'Skill Upgrading' block of results in table 4 show that there has been FTAinduced skill upgrading i.e., an increase in the ratio of non-production workers to production workers. This happened at the industry level much more than at the plant level which means that market shares have shifted in favour of non-production-worker-intensive plants. Possibly these workers are a fixed cost that is needed to penetrate U.S. markets.

\section{Earnings}

Most commentators expected Canadian wages to fall in response to competition from lessunionized, less-educated workers in the southern United States. Table 5 revisits this question 
using payroll statistics. Since the industry-level results are robust and since endogeneity is strongly rejected, I do not report the specifications that appeared as rows 5,6 , and 12 of tables 4. For all workers, the tariff concessions raised annual earnings. For example, the total FTA impact is a rise of 3 percent at both the industry level $(t=3.80)$ and the plant level $(t=5.64)$. At the plant level, earnings rose for both production and non-production workers. At the industry level, earnings gains were concentrated among production workers. ${ }^{16} \mathrm{I}$ have refined this observation by looking at hourly wages and hours worked by production workers. As shown in table 5 , there are wage effects and no hours effects. These earnings and wage effects are large in a statistical sense, but small in an economic sense. For example, a 3 percent rise in earnings spread over 8 years will buy you more than a cup of coffee, but not at Starbucks. The important finding is not that earnings went up, but that earnings did not go down in response to competitive pressures from the U.S. South.

There are a number of reasons why earnings may have risen slightly at a time when employment was falling. First, there may have been end-game bargaining on the part of unions seeking to extract rents from nearly-bankrupt firms as in Lawrence and Lawrence (1985). To investigate, I use the Canadian Labour Force Survey which reports unionization rates in 1996 for a classification in which manufacturing is divided up into 16 industries. The correlation of Canadian tariff concessions with union membership rates and union coverage rates is 0.016 and 0.002 , respectively. Thus, unionization does not offer an explanation of modestly rising earnings.

\footnotetext{
${ }^{16} \mathrm{My}$ earnings results contrast sharply with those of Gaston and Trefler (1997) and Beaulieu (2000). Gaston and Trefler found no statistically significant effect of the tariff concessions on earnings. The only effect Beaulieu finds is the positive effect of U.S. tariff concessions on non-production worker earnings (an effect I find only in the plant-level data, not the industry-level data). Once again, my improved data and methodology means that my results supersede older results.
} 
Another possibility is that workers in the most impacted industries upgraded their skills, possibly through the attrition of less-skilled workers. The Labour Force Survey is the most detailed source of data on education by industry. It reports education on a consistent basis back to 1988 (but not 1980). The correlation of Canadian tariff concessions $\Delta \tau_{i 1}^{C A}$ with 1988-96 log changes in average years of schooling is -0.28 which supports the view that the tariff cuts were associated with educational upgrading. However, this correlation is almost completely driven by the Clothing industry. The correlation falls to -0.06 when Clothing is omitted. Note of course that the Clothing industry is too important for an analysis of the FTA to simply be dismissed as an outlier. Thus, while there is some evidence that the earnings effect is driven in part by educational upgrading, this conclusion must be tentative.

The explanation of modestly rising earnings best supported by the data is seniority-based worker attrition. The Labour Force Survey reports current job tenure over the 1980-1996 period. Let $\Delta \ln$ Tenure $_{i s}$ be the average annual log change in tenure in the pre-FTA pe$\operatorname{riod}(s=0)$ or FTA period $(s=1)$. Figure 3 plots $\Delta \ln$ Tenure $_{i 1}-\Delta \ln$ Tenure $_{i 0}$ against $\Delta \tau_{i 1}^{C A}-\Delta \tau_{i 0}^{C A}$. That is, it has the form of my usual difference-of-differences estimator. As is apparent, industries that experienced the deepest tariff cuts (and hence the deepest employment losses) also experienced the largest increases in current job tenure. The correlation is -0.45 .

The wage results point to a potential caveat for the labour productivity results. The 5 percent earnings rise associated with the Canadian tariff concessions may in part reflect a rise in labour quality. At one extreme, if the earnings rise was entirely due to increased labour quality then labour productivity rose not by 15 percent, but by $15-5=10$ percent. This 
translates into a compound annual growth rate of 1.2 percent, still an enormous number. At the other extreme, if productivity increases drove wage increases (i.e., if there was no labour quality increase), then no correction to the productivity numbers is needed.

There is a presumption in the popular press that anything to do with globalization will worsen income inequality. It is thus reassuring that there is absolutely no evidence that the FTA worsened income inequality. In the last block of results in table 5, where inequality is measured as the earnings of non-production workers relative to production workers, $\widehat{\beta}^{C A}$ and $\widehat{\beta}^{U S}$ are effectively 0 .

\section{What Underlies Rising Labour Productivity?}

To the extent that the labour productivity benefits of the FTA reflect gains in technical efficiency (as opposed to allocative efficiency), it is of interest to know how this came about. This section examines three possibilities.

First, plants may have moved down their average cost curves. To examine this I estimated my industry-level equation (6) for average output per plant and my plant-level equation (7) for plant output. The results appear at the bottom of table 3 above. The industry-level $\widehat{\beta}^{C A}$ and $\widehat{\beta}^{U S}$ are comparable in magnitude to those estimated by Head and Ries (1999b) though my significance level is much lower. ${ }^{17}$ Their finding of statistical significance may reflect their decision to work with annual changes without correcting for serial correlation. The more interesting results are at the plant level since these are more readily interpretable as moving along an average cost curve. The results indicate that the Canadian tariff concessions led

\footnotetext{
${ }^{17}$ Head and Ries find $\widehat{\beta}^{C A}=-0.11$ with $t=3.08$ and $\widehat{\beta}^{U S}=.06$ with $t=2.74$. (For comparability, I have scaled their estimates.)
} 
the most-impacted, import-competing plants to contract by 5 percent $(t=1.36)$ while the U.S. tariff concessions led the most-impacted, export-oriented plants to expand by 6 percent $(t=2.01)$. These are not statistically significant results. Thus, this is not strong evidence in support of a simple scale effects explanation of labour productivity gains.

Second, the popular press reports that U.S.-owned multinationals have been reorganizing their Canadian plants in order to produce fewer product lines, each with a global mandate. This is consistent with Baldwin and Beckstead (2001) who find that for foreignowned plants operating in Canada, increases in exports are associated with reductions in the number of commodities produced. Thus, plant rationalization may have contributed to rising productivity.

Third, it is possible that my FTA-induced labour productivity gains do not extend to TFP gains. However, this seems unlikely since there is little evidence of capital deepening, more intensive use of intermediate inputs, or rising mark-ups. Specifically, using my difference-of-differences methodology, Trefler (2001) finds (1) no evidence of capital deepening at the 3-digit SIC level (capital stock is not available at the 4-digit level), (2) evidence of only very modest increases in the usage of intermediate inputs at the 4-digit SIC level, and (3) no evidence of increased mark-ups (not a surprise given that the most-impacted import-competing industries are low-end manufacturing industries with low mark-ups to begin with). Thus, the Hall (1988) TFP calculation shows that TFP must have risen substantially. More exactly, Trefler (2001) argues that the FTA-induced TFP changes are roughly half of the labour productivity changes. That is, the TFP changes are huge. 


\section{Conclusions}

There are many ways in which the Canada-U.S. Free Trade Agreement provides a unique window onto the effects of freer trade. The FTA was a relatively clean policy experiment, untainted by macro shocks or financial crises. It was an agreement between two industrialized countries. It was a reciprocal agreement, which means it effected exporters, not just importers. In contrast, most previous studies of trade liberalization have dealt with the unilateral trade actions of a developing country. Several strong conclusions emerged from the analysis. First, the FTA was associated with substantial employment losses: 12 percent for the most-impacted, import competing group of industries and 5 percent for manufacturing as a whole. These effects appear in both the industry- and plant-level analyses. Second, the FTA led to large labour productivity gains. For the most-impacted, export-oriented group of industries, labour productivity rose by 14 percent at the plant level. For the most-impacted, import-competing group of industries, labour productivity rose by 15 percent with at least half of this coming from the exit and/or contraction of low-productivity plants. For manufacturing as a whole, labour productivity rose by about 6 percent which is remarkable given that much of manufacturing was duty free before implementation of the FTA. Third, the FTA created more trade than it diverted and possibly lowered import prices. Thus, the FTA likely raised aggregate welfare.

The FTA is the well spring of one of the most heated political debates in Canada. This heat is generated by the conflict between those who bore the short run adjustment costs (displaced workers and stakeholders of closed plants) and those who are garnering the long run gains (stakeholders of efficient plants, consumers, and purchasers of intermediate 
inputs). One cannot understand current debates about freer trade without understanding this conflict. Unfortunately, much of the academic debate has been fragmented: one set of researchers has focussed on the short-run adjustment costs of worker displacement while another has focussed on the long-run productivity gains. While this paper does not provide the silver bullet that makes the case either for or against free trade, I believe that it has considerably refined the question. My hope is that the results here take us one step closer to understanding how freer trade can be implemented in an industrialized economy in a way that recognizes both the long-run gains and the short-run adjustment costs borne by workers and others. 


\section{Appendix}

\section{A. Tariff Details}

The Canadian tariff data were supplied by Statistics Canada at the 4-digit SIC level. The U.S. tariff data were constructed as follows. The 1980-88 data were converted from the TSUSA classification system (approximately 10,000 products) to SITC(revision 2) (approximately 800 products) using Feenstra's (1996) converter. It was then converted to Canadian SIC (213 industries) using a converter supplied by Statistics Canada. This converter was largely unique, but where not, weights for pro-rating data across SIC industries were supplied by Statistics Canada. For 1989-94 tariff rates, the same procedure was followed, but starting from HS10 rather than TSUSA. For 1996 data, I converted the Census Bureau's 'U.S. Imports of Merchandise: December 1996' (CD-96-12) data from HS10 to SITC(revision 3) using the supplied converter. I then converted the data to SITC(revision 2) using an almost 1:1 converter supplied by Feenstra (1996) and proceeded as with the 1980-88 data.

Of Canada's 225 4-digit SIC industries, 4 were excluded from the analysis because of incomplete data and another 16 were aggregated into 8 categories in order to ensure consistency of the trade and tariff data over time. The aggregated industries are: 1094 and 1099; 1511 and 1599; 1995 and 1999; 2911 and 2919; 2951 and 2959; 3051 and 3059; 3351 and $3359 ; 3362$ and 3369.

The tariff data are defined as duties divided by imports. These data are collected at the tariff-line level (e.g., HS10 after 1988). I have compared a large number of the tariff rates so derived with published statutory tariff rates. The two tariff rate series are the same. A key issue is how to aggregate the tariff-line data up to the 4-digit SIC level. Since imports are the only data reported at a comparable level of disaggregation, I must follow what all empirical trade researchers do and aggregate using import weights. This is accomplished in the usual way as follows. Consider a single 4-digit SIC industry, let $i$ be an HS10 item feeding into the industry, let $I$ be the set of HS10 items feeding into the industry, let $\tau_{i t}$ be the tariff rate and let $m_{i t}$ be the share of the industry's imports accounted for by product $i$. My tariff rate changes have the form $\Delta \tau \equiv \Sigma_{i \epsilon I} \tau_{i t} m_{i t}-\Sigma_{i \epsilon I} \tau_{i, t-1} m_{i, t-1}$. For later reference, $\Delta \tau=\Sigma_{i \epsilon I}\left(\tau_{i t}-\tau_{i, t-1}\right) m_{i t}-\Sigma_{i \in I}\left(m_{i t}-m_{i, t-1}\right) \tau_{i, t-1}$.

Ideally I would prefer to use fixed-weight tariffs $\Delta \tau^{\text {fixed }}=\Sigma_{i \in I}\left(\tau_{i t}-\tau_{i, t-1}\right) m_{i, t-1}$. However this can not be calculated because about one third of all 1988 HS10 items disappeared by 1996. (Companies often hire lawyers to have their HS10 reallocated to a higher tar-

iff HS10.) To get a handle on the difference between $\Delta \tau^{\text {fixed }}$ and $\Delta \tau$, I manipulated the estimates of $\Delta \tau^{\text {fixed }}$ that were used by the Government of Canada in its pre-FTA assessment of the likely impacts of the agreement (Magun et al. 1988). To understand what I did note that most industries had their tariffs reduced to 0 linearly either over 5 years or 10 years. Using Magun et al. (1988) I classified 4-digit SIC industries into either the 5- or 10-year category. (The Magun et al. study reported estimates of $\Delta \tau^{\text {fixed }}$ using an input-output table classification that breaks manufacturing into about 60 industries.) In the formula $\Delta \tau^{\text {fixed }}=\Sigma_{i \epsilon I}\left(\tau_{i, 1996}-\tau_{i, 1988}\right) m_{i, 1988}$ I set $\tau_{i, 1996}=0$ for 5 -year industries and $\tau_{i, 1996}=0.20 \tau_{i, 1988}$ for 10-year industries. This allows me to compute $\Delta \tau^{\text {fixed }}$.

The outcome of this procedure is estimates of $\Delta \tau_{i 1}^{C A, \text { fixed }}$ and $\Delta \tau_{i 1}^{U S, \text { fixed }}$ where I am using 
the notation of equation (2). Across 4-digit SIC industries the correlation of $\Delta \tau_{i 1}^{C A, f i x e d}$ with $\Delta \tau_{i 1}^{C A}$ is 0.98 and the correlation of $\Delta \tau_{i 1}^{U S, f i x e d}$ with $\Delta \tau_{i 1}^{U S}$ is 0.97 . That is, my tariff rate changes are very similar to a best estimate of fixed-weight tariff changes. Not surprisingly, the two tariff-change series yield almost identical results for estimates of $\beta^{C A}$ and $\beta^{U S}$. Trefler (2001, appendix 2) discusses further aspects of aggregation.

Table A1 reports $\Delta \tau_{i 1}^{C A}$ and $\Delta \tau_{i 1}^{U S}$ for the most-impacted, import-competing industries.

\section{B. Scaling $\beta^{C A}$ and $\beta^{U S}$ and Defining 'Total FTA Impact'}

Recall that $Y_{i, 1988}$ is the level of, say employment, in industry $i$ in 1988 . The industry $i$ change in employment over the FTA period is approximately $8\left(\Delta y_{i 1}\right) Y_{i, 1988}$ i.e., the $\log$ change times the initial level. Multiplying by 8 converts the average annual changes for the 8 FTA years into a total FTA period change. The change in employment among industries in any set $I$ is approximately $8 \sum_{i \epsilon I}\left(\Delta y_{i 1}\right) Y_{i, 1988}$. As a proportion of total employment it is $8 \sum_{i \in I} \Delta y_{i 1} \omega_{i}$ where $\omega_{i} \equiv Y_{i, 1988} / \sum_{j \in I} Y_{j, 1988}{ }^{18}$ Using the fact that $8{\widehat{\Delta y_{i 1}}}^{18}=8 \widehat{\beta}^{k} \Delta \tau_{i 1}^{k}$ $(k=C A, U S)$ is the predicted impact of country $k$ 's tariff concessions in industry $i$, the predicted tariff-induced log change in employment is $8 \sum_{i \in I} \widehat{\beta}^{k} \Delta \tau_{i 1}^{k} \omega_{i}$ where $I$ is the set of industries in the most-impacted, import-competing industries $(k=C A)$ or export-oriented industries $(k=U S)$. Defining $\overline{\Delta \tau}_{\cdot 1}^{k} \equiv 8 \Sigma_{i \in I} \Delta \tau_{i 1}^{k} \omega_{i}$, the predicted impact reduces to $\widehat{\beta}^{k} \overline{\Delta \tau}_{\cdot 1}^{k}$ which is what is reported in the tables.

\section{Estimation of $\Delta b_{i s}$}

As noted in section 4 , construction of $\Delta b_{i s}$ requires the preliminary step of estimating

$$
\Delta_{1} y_{i t}=\theta_{i}+\Sigma_{j=0}^{J} \theta_{i j} \Delta_{1} z_{t-j}+\eta_{i t}
$$

I use OLS since my only criterion is to minimize in-sample prediction error. This regression was estimated separately for each industry using 1983-96 data. (As discussed in footnote ??, I do not have data for 1981 and 1982.) This leaves only 13 observations for estimating 7 parameters. $\left(\theta_{i 0}, \theta_{i 1}\right.$, and $\theta_{i 2}$ are each tuples.) To modestly increase the degrees of freedom, I estimated the regression at the 3-digit SIC industry level rather than at the 4-digit SIC industry level. There is not much difference between the 3 - and 4-digit $\Delta b_{\text {is }}$ as can be seen from the fact that on average there are only 2.03 4-digit industries per 3-digit industry.

Since $\Delta b_{i s}$ is a generated regressor, I re-estimated all my results for the case where $\Delta b_{i 1}-\Delta b_{i 0}$ is an endogenous regressor in equations (6) and (7). This had no impact on the results. Further tests of mis-specification due to a generated regressor led to rejection of mis-specification.

\footnotetext{
${ }^{18}$ There are some exceptions to this definition of $\omega_{i}$. For the cases of production worker earnings and wages, $\omega_{i}$ is based on total hours worked by production workers. For the cases of skill upgrading and inequality $\omega_{i}$ is based on total employment. For intra-industry trade, $\omega_{i}$ is based on Canadian imports from the United States. Otherwise, if $Y_{i, 1988}$ is a ratio then $\omega_{i}$ is based on the numerator of the ratio i.e., if $Y_{i, 1988}=a_{i, 1988} / b_{i, 1988}$ then $\omega_{i} \equiv a_{i, 1988} / \sum_{j \in I} a_{j, 1988}$.
} 
Appendix table A2 reports results for different choices of years. As is apparent, the results do not change substantially as long as the FTA baseline year is 1988. A referee has suggested that I also report results for the periods 1981-88 and 1989-96. Since the worst of the FTA adjustment happened immediately, the use of 1989 as the FTA baseline period means that I miss at least some of the adjustment. Indeed, the estimated coefficients are somewhat smaller.

\section{Measuring Labour Productivity}

Table A3 reports the results for labour productivity using 3 alternative measures of labour productivity. The most commonly used measure of labour productivity at the industry level is value added per worker deflated by an output deflator. This is the third measure reported in table A3. There are several defects with this measure, two of which are easily addressed.

The first deals with the measurement of labour input. In Canada, but not in the United States, there has been a strong trend towards part-time employment. By not correcting for Canadian hours, measure 3 has a downward trend. Since this trend will be spuriously correlated with the downward trend in tariffs, the estimated effect of the FTA on productivity $\left(\widehat{\beta}^{C A}\right.$ and $\left.\widehat{\beta}^{U S}\right)$ will be downward biased. The Canadian data allow for an hours correction. Unlike the U.S. data, value added is reported for production activities alone and thus can be directly compared with the data reported for hours worked. Measure 1 of table A3 reports the estimates using Canadian real value added in production activities per hour worked and U.S. real value added in all activities per employee. This is the same measure used in table 2. As expected, the estimates tend to be larger for measure 1 than for measure 3 (though both are large). Clearly, measure 1 is preferred.

The second data issue deals with deflators. In table A3, measures 1 and 3 use output deflators while measure 2 uses value-added deflators. Value-added deflators would have been preferable had the U.S. deflator not been seriously flawed for present purposes. It is at the 2-digit level (20 industries) and even at this highly aggregated level there are imputations for instruments (SIC 38) and electric and electronic equipment (SIC 36). Measure 2 of table $\mathrm{A} 3$, the value added-deflated measure, thus has serious problems. This said, the $\left(\widehat{\beta}^{C A}, \widehat{\beta}^{U S}\right)$ based on value-added deflators are very similar to the $\left(\widehat{\beta}^{C A}, \widehat{\beta}^{U S}\right)$ based on output deflators. This can be seen by comparing measures 1 and 2 in table A3. See Trefler (2001, appendix 4) for a detailed discussion of deflators.

\section{E. Plant Selection Issues}

As noted in section 2.5, my results apply to long-form plants that were in existence in 1980, 1986, 1988, and 1996. These tend to be large plants. For example, in 1988 the average longform plant was 2.2 times larger than the all-plant average. Note that the average long-form continuing plant was only 2.1 times larger than the all-continuing-plant average so that the large size of my plants is due to the fact that they are long-form rather than continuing per se. 
The available evidence suggests that long-form selection issues are of secondary importance in the current context. To see this, I begin by noting that almost every plant in Canada receives either a long-form or short-form survey so that almost the entire universe of Canadian plants are surveyed. Next, for the few industry outcomes available in the short-form survey (employment, earnings, output, and a measure of labour productivity), the estimates of $\beta^{C A}$ and $\beta^{U S}$ based on long-form and on long-form plus short-form plants are very similar. The exception is the estimate of $\beta^{U S}$ for employment. It implies employment losses of -4 percent using the long-form plants and -6.7 percent using long-form plus short-form plants. Thus, the conclusions from the long-form continuing plants appear to be broadly representative of all continuing plants. 


\section{References}

Arellano, Manuel and Bo Honoré, "Panel Data Models: Some Recent Developments," in James J. Heckman and Edward Leamer, eds., Handbook of Econometrics, Vol. 5, Amsterdam: North-Holland, 2001, pp. 3229-3296.

Baldwin, John R., The Dynamics of Industrial Competition: A North American Perspective, Cambridge, MA: Cambridge University Press, 1995.

- and Desmond Beckstead, "Changes in the Diversification of Canadian Manufacturing Firms (1973-1997)," Mimeo, Statistics Canada, 2001.

- and Wulong Gu, "The Effect of Exporting on Productivity Growth in Canadian Manufacturing," Mimeo, Statistics Canada, October 2001.

Bartelsman, Eric J. and Wayne Gray, "The NBER Manufacturing Productivity Database," Technical Working Paper No. 205, National Bureau of Economic Research, October 1996.

Beaulieu, Eugene, "The Canada-U.S. Free Trade Agreement and Labour Market Adjustment in Canada," Canadian Journal of Economics, May 2000, 33 (2), 540-63.

Bernard, Andrew B. and J. Bradford Jensen, "Exporters, Jobs, and Wages in U.S. Manufacturing: 1976-1987," Brookings Papers on Economic Activity, 1995, Microeconomics, 67-112.

_ and _ , "Exceptional Exporter Performance: Cause, Effect, or Both?," Journal of International Economics, 1999, 47 (1).

Claussing, Kimberly A., "Trade Creation and Trade Diversion in the Canada-United States Free Trade Agreement," Canadian Journal of Economics, August 2001, 34 (3), $677-696$.

Corden, W. M., Trade Policy and Economic Welfare, Oxford: Clarendon Press, 1974.

Currie, Janet and Ann E. Harrison, "Sharing the Costs: The Impact of Trade Reform on Capital and Labor in Morocco," Journal of Labor Economics, July 1997, 15 (3), S4471.

Feenstra, Robert C., "U.S. Imports, 1972-1994: Data and Concordances," Working Paper No. 5515, National Bureau of Economic Research, March 1996.

Finger, J. Michael, H. Keith Hall, and Douglas R. Nelson, "The Political Economy of Administered Protection," American Economic Review, June 1982, I2 (3), 452-466.

Gaston, Noel and Daniel Trefler, "Protection, Trade, and Wages: Evidence from U.S. Manufacturing," Industrial and Labor Relations Review, July 1994, 47 (4), 574-593.

_ and _, "Union Wage Sensitivity to Trade and Protection: Theory and Evidence," Journal of International Economics, August 1995, 39 (1-2), 1-25. 
_ and _ , "The Labour Market Consequences of the Canada-U.S. Free Trade Agreement," Canadian Journal of Economics, February 1997, 30 (1), 18-41.

Hall, Robert E., "The Relation between Price and Marginal Cost in U.S. Industry," Journal of Political Economy, October 1988, 96 (5), 921-947.

Harrison, Ann and Ana Revenga, "The Effects of Trade Policy Reform: What Do We Really Know?," Working Paper No. 5225, National Bureau of Economic Research, August 1995.

- and Gordon H. Hanson, "Who Gains from Trade Reform? Some Remaining Puzzles," Working Paper No. 6915, National Bureau of Economic Research, January 1999.

Harrison, Ann E., "Productivity, Imperfect Competition and Trade Reform: Theory and Evidence," Journal of International Economics, February 1994, 36 (1-2), 53-73.

Head, Keith and John Ries, "Can Small-Country Manufacturing Survive Trade Liberalization? Evidence from the Canada-U.S. Free Trade Agreement," Perspectives on North American Free Research Publication No. 1, Industry Canada, April 1999.

- and _, "Rationalization Effects of Tariff Reductions," Journal of International Economics, April 1999, 47 (2), 295-320.

_ and _, "Increasing Returns versus National Product Differentiation as an Explanation for the Pattern of U.S.-Canada Trade," American Economic Review, September 2001, 91 (4), 858-876.

Helleiner, Gerald K., "Introduction," in Gerald K. Helleiner, ed., Trade Policy and Industrialization in Turbulent Times, London: Routledge, 1994, pp. 1-36.

Huber, J. Richard, "Effect on Prices of Japan's Entry into World Commerce after 1858," Journal of Political Economy, May-June 1971, 79 (3), 614-628.

Krishna, Pravin, "Are Regional Trading Partners "Natural"?," Journal of Political Economy, February 2003, 111 (1), 202-226.

- and Devashish Mitra, "Trade Liberalization, Market Discipline and Productivity Growth: New Evidence From India," Journal of Development Economics, August 1998, $56(2), 447-462$.

_, _, and Sajjid Chinoy, "Trade Liberalization and Labor Demand Elasticities: Evidence from Turkey," Journal of International Economics, December 2001, 55 (2), 391-409.

Krueger, Anne O., "Trade Policy and Economic Development: How We Learn," American Economic Review, March 1997, 87 (1), 391-409.

Lai, Huiwen and Daniel Trefler, "The Gains from Trade with Monopolistic Competition: Specification, Estimation, and Mis-Specification," Working Paper No. 9169, National Bureau of Economic Research, September 2002. 
Lawrence, Colin and Robert Z. Lawrence, "Manufacturing Wage Dispersion: An End Game Interpretation," Brookings Papers on Economic Activity, 1985, 1, 47-106.

Levinsohn, James, "Testing the Imports-as-Market-Discipline Hypothesis," Journal of International Economics, August 1993, 35 (1-2), 1-22.

_ , "Employment Responses to International Liberalization in Chile," Journal of International Economics, April 1999, $4^{\text {r }}$ (2), 321-344.

Magun, S., S. Rao, B. Lodh, L. Lavall, and J. Pierce, "Open Borders: An Assessment of the Canada-U.S. Free Trade Agreement," Discussion Paper 344, Economic Council of Canada,, Ottawa 1988.

Nelson, Charles R. and Richard Startz, "Some Further Results on the Exact Small Sample Properties of the Instrumental Variables Estimator," Econometrica, July 1990, $58(4), 967-976$.

Panagariya, Arvind, "Preferential Trade Liberalization: The Traditional Theory and New Developments," Journal of Economic Literature, June 2000, 38 (2), 287-331.

Pavcnik, Nina, "Trade Liberalization, Exit, and Productivity Improvement: Evidence from Chilean Plants," Review of Economic Studies, 2002, 69 (1), 245-276.

Revenga, Ana, "Employment and Wage Effects of Trade Liberalization: The Case of Mexican Manufacturing," Journal of Labor Economics, 1997, 15 (3), S20-43.

Rodriguez, Francisco and Dani Rodrik, "Trade Policy and Economic Growth: A Skeptic's Guide to the Cross-National Evidence," Discussion Paper No. 2143, Centre for Economic Policy Research, May 1999.

Schott, Peter K., "Do Rich and Poor Countries Specialize in a Different Mix of Goods? Evidence from Product-Level US Trade Data," Working Paper No. 8492, National Bureau of Economic Research, September 2001.

Trefler, Daniel, "Trade Liberalization and the Theory of Endogenous Protection: An Econometric Study of U.S. Import Policy," Journal of Political Economy, February 1993, 101 (1), 138-160.

_ , "The Long and Short of the Canada-U.S. Free Trade Agreement," Working Paper No. 8293, National Bureau of Economic Research, May 2001.

Tybout, James R., "Manufacturing Firms in Developing Countries: How Well Do They Do, and Why?," Journal of Economic Literature, March 2000, 38 (1), 11-44.

_ and M. Daniel Westbrook, "Trade Liberalization and the Dimensions of Efficiency Change in Mexican Manufacturing Industries," Journal of International Economics, August 1995, 39 (1-2), 53-78. 
_, Jamie de Melo, and Vittorio Corbo, "The Effects of Trade Reforms on Scale and Technical Efficiency," Journal of International Economics, November 1991, 31 (3-4), $231-250$.

Wooldridge, Jeffrey M., Econometric Analysis of Cross Section and Panel Data, Cambridge, MA: MIT Press, 2002. 
Figure 1. Canadian and U.S. Bilateral Tariffs in Manufacturing

The Average Canadian Tariff Rate Against:

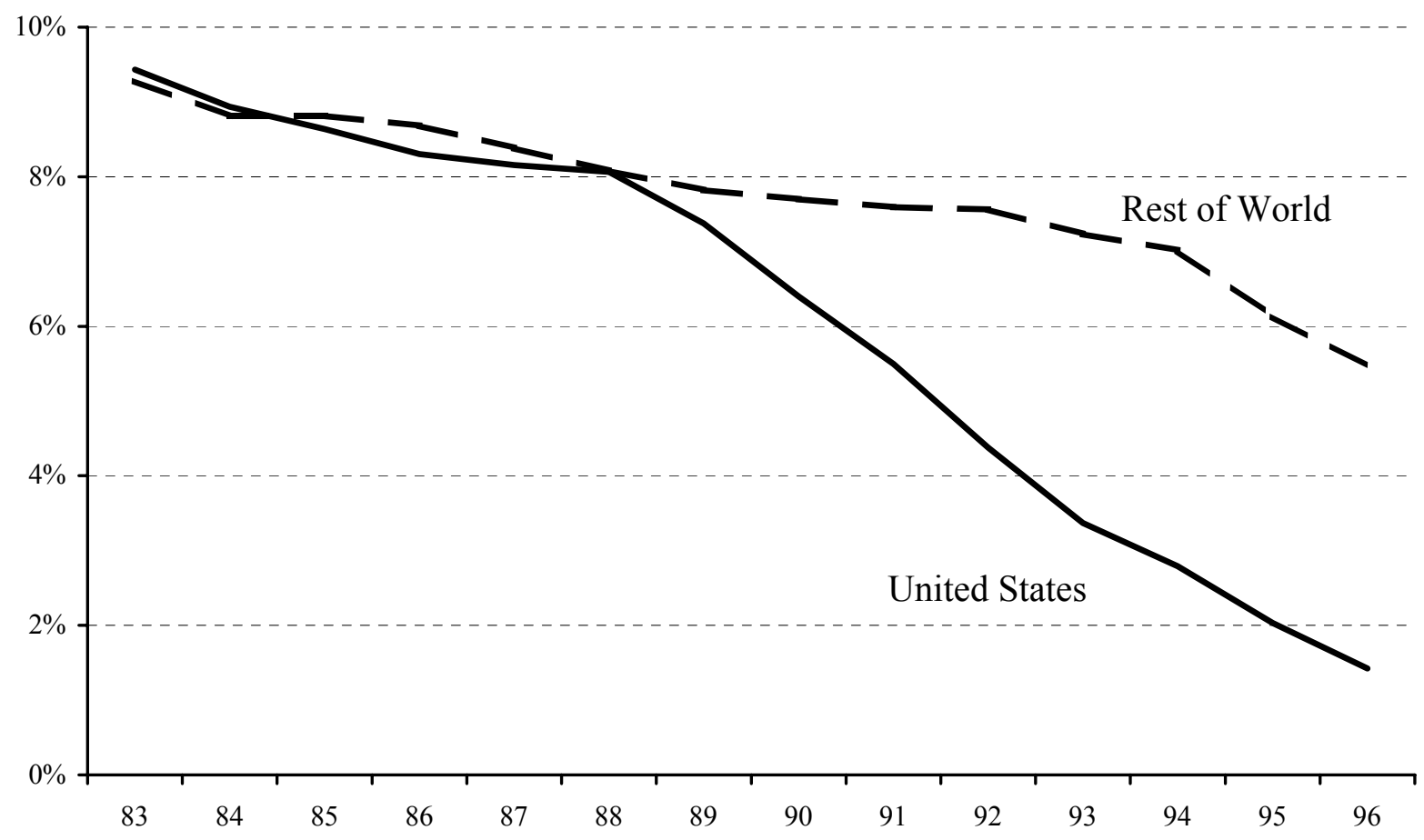

The Average U.S. Tariff Rate Against:

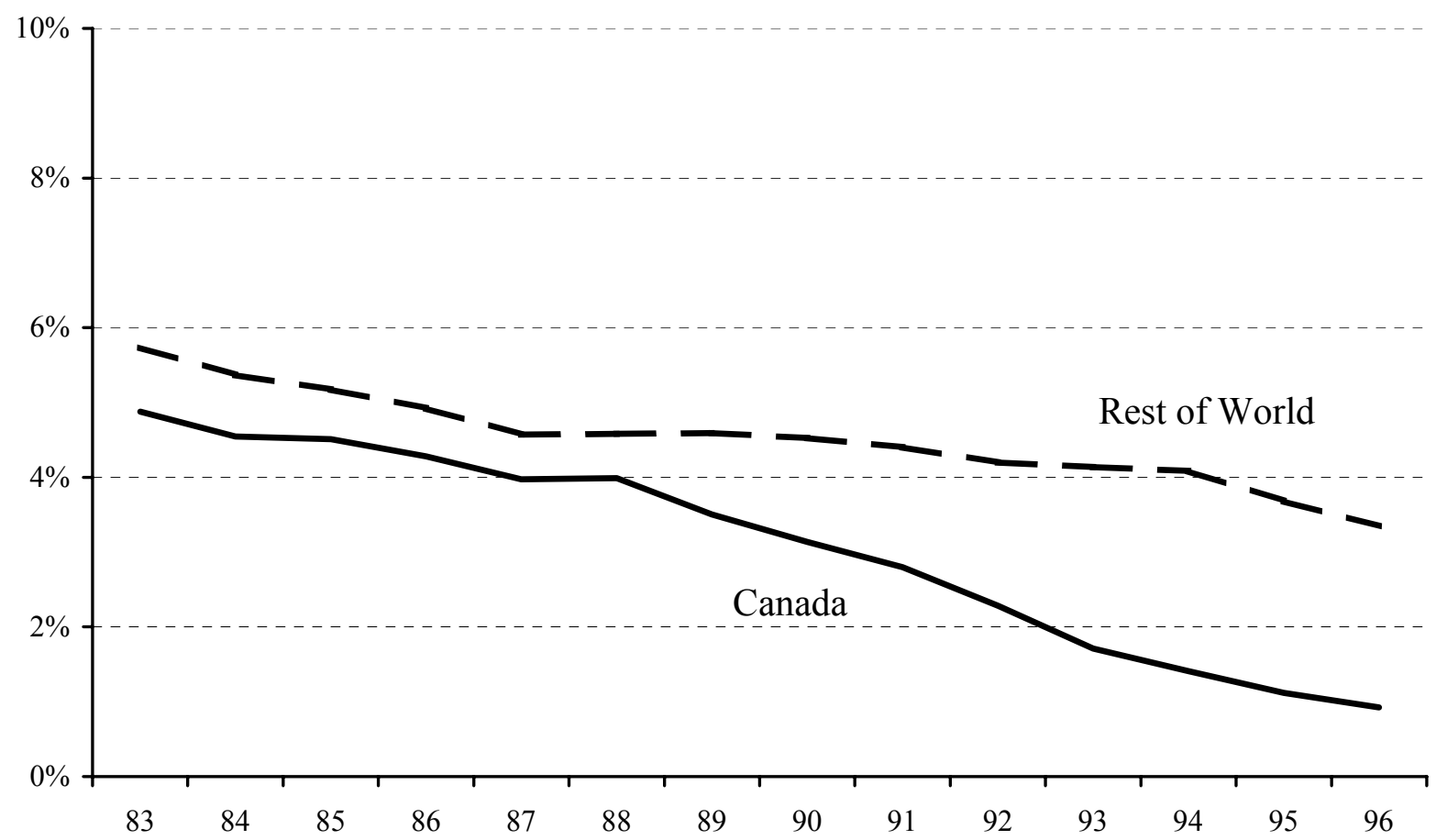




\section{Figure 2. Real Canadian Manufacturing GDP}

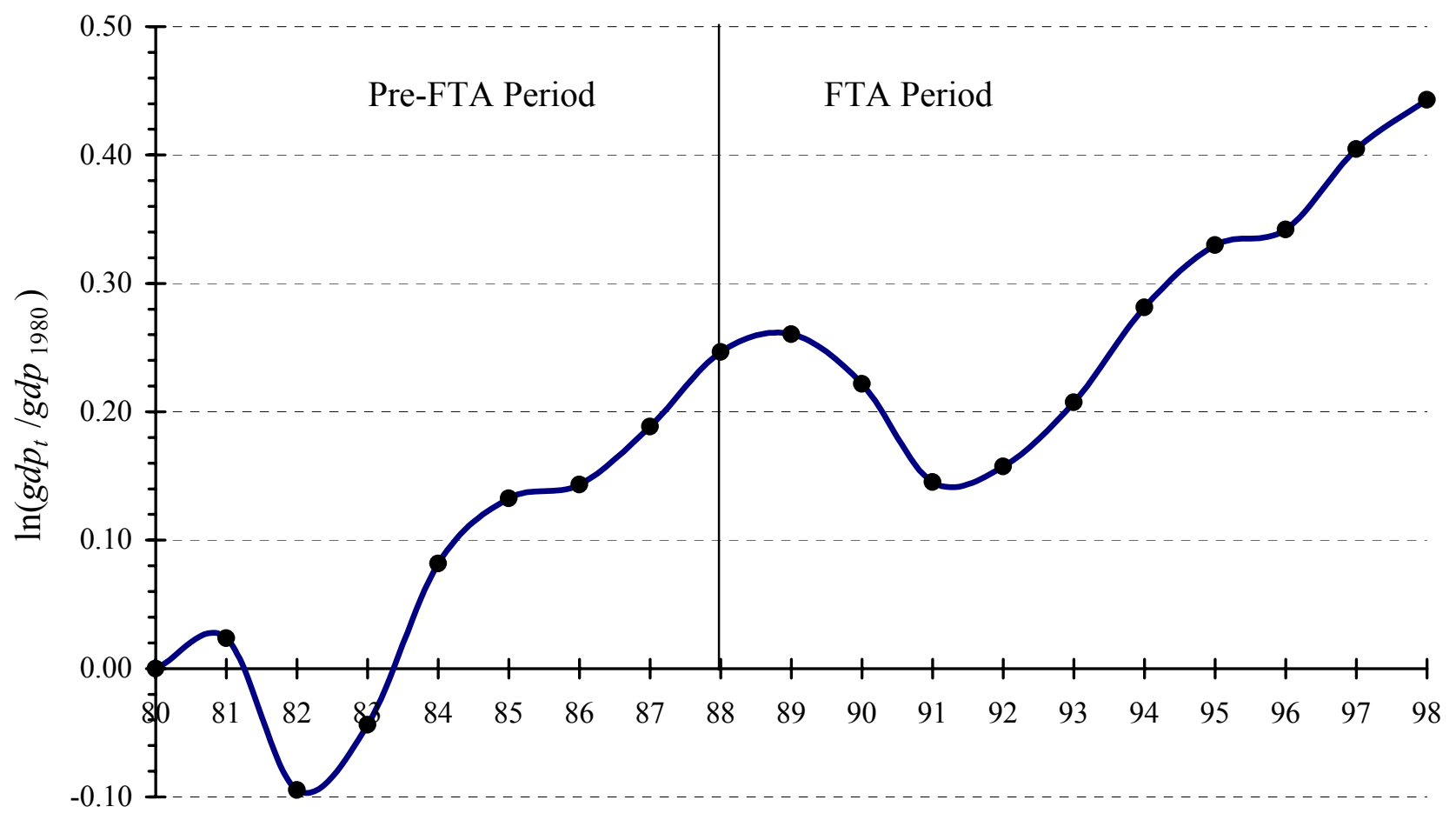

Notes : Data are from the series 'gdp at factor cost, 1992 dollars' from Statistics Canada's CANSIM database. 
Fig. 3. Current Job Tenure Changes [(96-88) less (86-80)] vs. Canadian Tariff Concessions

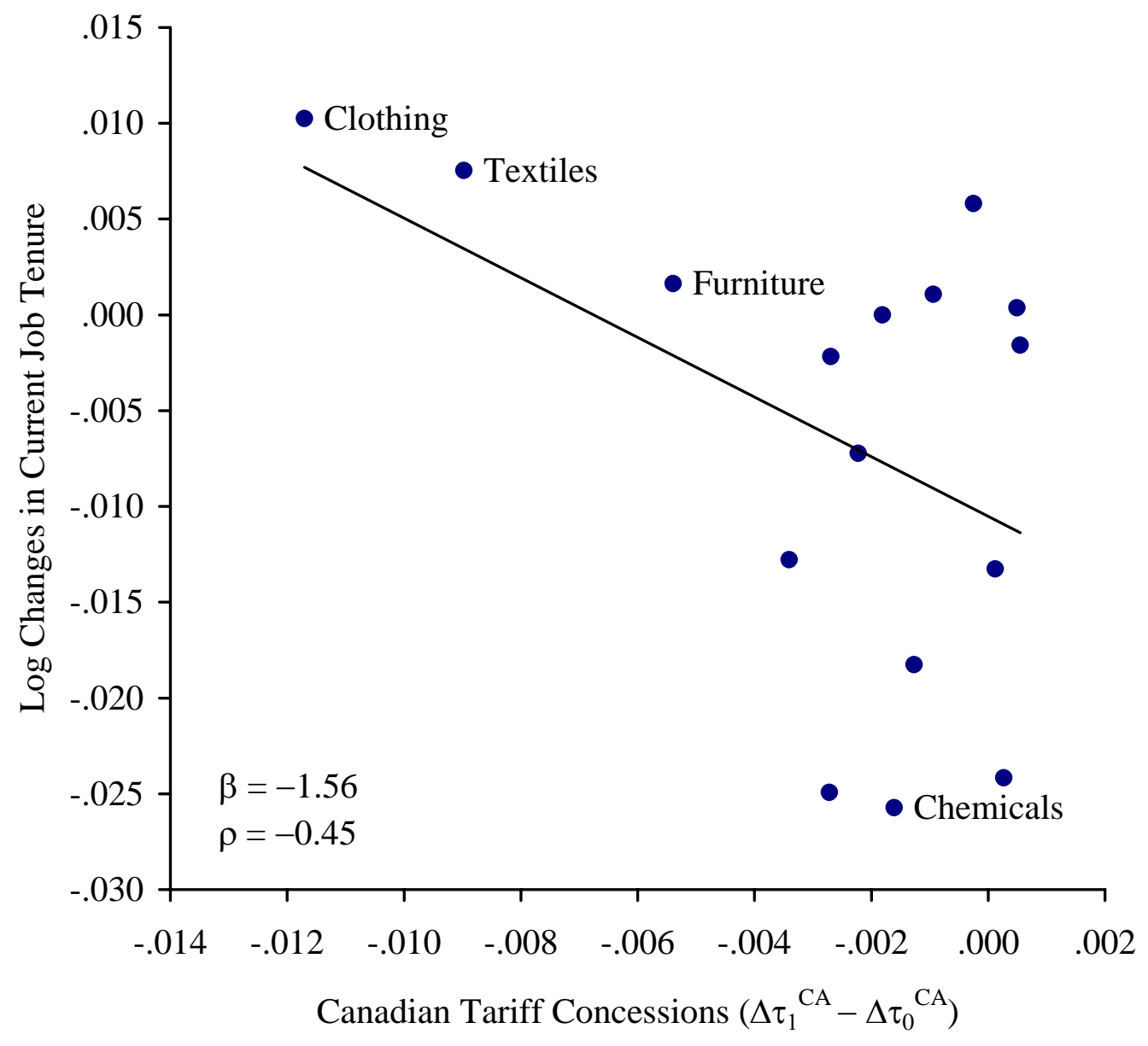


Table 1. Detailed Results for Employment

\begin{tabular}{|c|c|c|c|c|c|c|c|c|c|c|c|c|c|}
\hline \multirow{2}{*}{\multicolumn{2}{|c|}{$\begin{array}{l}\text { Construction } \\
\text { of } \Delta b \\
\end{array}$}} & \multicolumn{2}{|c|}{$\begin{array}{c}\text { Canadian } \\
\text { Tariffs } \Delta \tau^{C A}\end{array}$} & \multicolumn{2}{|c|}{$\begin{array}{c}\text { U.S. Tariffs } \\
\qquad \Delta \tau^{U S}\end{array}$} & \multicolumn{2}{|c|}{$\begin{array}{c}\text { Business } \\
\text { Conditions } \Delta b\end{array}$} & \multicolumn{2}{|c|}{$\begin{array}{l}\text { U.S. Control } \\
\qquad y^{U S}\end{array}$} & \multirow{2}{*}{$\begin{array}{c}\text { Adj. } \\
R^{2}\end{array}$} & \multirow{2}{*}{$\begin{array}{c}\text { OverId / } \\
\text { Hausman } \\
\end{array}$} & \multicolumn{2}{|c|}{$\begin{array}{l}\text { Total FTA } \\
\text { Impact }\end{array}$} \\
\hline & & $\beta^{C A}$ & $t$ & $\beta^{U S}$ & $t$ & $\delta$ & $t$ & $\gamma$ & $t$ & & & TFI & $t$ \\
\hline \multicolumn{14}{|c|}{ Industry Level, OLS } \\
\hline 1 & gdp, rer (2) & -.12 & -2.35 & -.03 & -0.67 & .29 & 6.96 & .15 & 2.21 & .24 & & -.05 & -2.66 \\
\hline 2 & gdp, rer (0) & -.11 & -2.03 & -.04 & -0.91 & .30 & 3.66 & .21 & 2.75 & .12 & & -.06 & -2.58 \\
\hline 3 & $g d p(2)$ & -.11 & -2.08 & -.03 & -0.66 & .37 & 6.60 & .15 & 2.16 & .23 & & -.05 & -2.41 \\
\hline $4^{e}$ & -- & -.14 & -2.40 & -.02 & -0.52 & & & .20 & 2.58 & .07 & & -.06 & -2.58 \\
\hline & gdp, rer (2) & -.13 & -2.48 & -.02 & -0.39 & .28 & 6.74 & .29 & 3.00 & .24 & & -.05 & -1.71 \\
\hline 6 & gdp, rer (2) & -.14 & -2.75 & -.03 & -0.80 & .30 & 7.12 & & & .23 & & -.06 & -3.16 \\
\hline $7^{e}$ & -- & -.17 & -2.88 & -.03 & -0.66 & & & & & .04 & & -.07 & -3.15 \\
\hline $8^{e}$ & gdp, rer (2) & -.14 & -2.24 & -.02 & -0.53 & .29 & 6.89 & .15 & 2.11 & .24 & & -.06 & -2.65 \\
\hline $9^{e}$ & gdp, rer (2) & -.12 & -2.30 & -.06 & -1.45 & .30 & 7.23 & .14 & 2.04 & .27 & & -.06 & -3.24 \\
\hline \multicolumn{14}{|c|}{ Plant Level, OLS } \\
\hline & gdp, rer (2) & -.12 & -3.76 & .00 & 0.15 & .13 & 4.59 & .25 & 5.29 & .04 & & -.04 & -3.26 \\
\hline & gdp, rer (2) & -.12 & -3.60 & -.01 & -0.26 & .16 & 5.63 & .25 & 5.21 & .02 & & -.04 & -3.51 \\
\hline \multicolumn{14}{|c|}{ Industry Level, IV } \\
\hline & gdp, rer (2) & -.24 & -1.45 & .09 & 0.66 & .29 & 6.68 & .15 & 2.06 & .22 & $.60 / .65$ & -.04 & -1.26 \\
\hline & gdp, rer (2) & -.24 & -1.43 & .04 & 0.29 & .31 & 6.37 & -.16 & -0.50 & .20 & $.67 / .57$ & -.05 & -1.57 \\
\hline \multicolumn{14}{|c|}{ Plant Level, IV } \\
\hline & e gdp, rer (2) & -.19 & -2.40 & .07 & 0.94 & .13 & 4.30 & .24 & 4.96 & .04 & $.14 / .99$ & -.04 & -2.55 \\
\hline & ${ }^{e}$ gdp, rer (2) & -.19 & -2.44 & .07 & 0.92 & .13 & 4.17 & .16 & 0.95 & .03 & $.10 / .89$ & -.04 & -3.10 \\
\hline
\end{tabular}

Notes:

a) The dependent variable is the log of employment. The estimating equation is equation (6) for the industry-level regressions and equation (7) for the plant-level regressions.

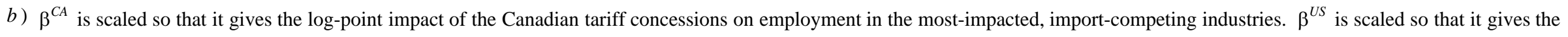

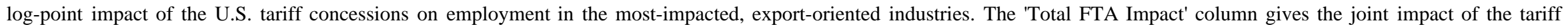
concessions on employment in all 213 industries.

c) The 'OverId/Hausman' column reports $p$-values for the over-identification and Hausman tests. Rejection of the instrument set or exogeneity are indicated by $p$-values less than 0.01 .

d) The number of observations is 213 for the industry-level regressions and 3,801 for the plant-level regressions.

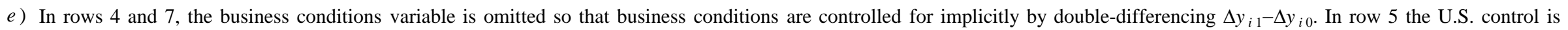

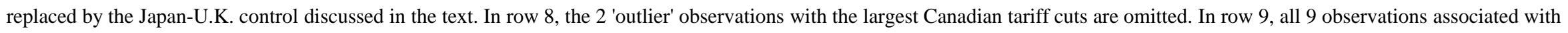

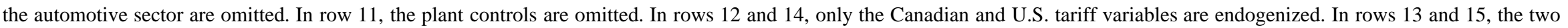
tariff variables and the U.S. control are endogenized. 
Table 2. Detailed Results for Labour Productivity

\begin{tabular}{|c|c|c|c|c|c|c|c|c|c|c|c|c|c|}
\hline & \multirow{2}{*}{$\begin{array}{l}\text { Construction } \\
\text { of } \Delta b \\
\end{array}$} & \multicolumn{2}{|c|}{$\begin{array}{c}\text { Canadian } \\
\text { Tariffs } \Delta \tau^{C A}\end{array}$} & \multicolumn{2}{|c|}{$\begin{array}{c}\text { U.S. Tariffs } \\
\Delta \tau^{U S}\end{array}$} & \multicolumn{2}{|c|}{$\begin{array}{c}\text { Business } \\
\text { Conditions } \Delta b\end{array}$} & \multicolumn{2}{|c|}{$\begin{array}{l}\text { U.S. Control } \\
\Delta y^{U S}\end{array}$} & \multirow{2}{*}{$\begin{array}{l}\text { Adj. } \\
R^{2} \\
\end{array}$} & \multirow{2}{*}{$\begin{array}{c}\text { OverId / } \\
\text { Hausman } \\
\end{array}$} & \multicolumn{2}{|c|}{$\begin{array}{c}\text { Total FTA } \\
\text { Impact }\end{array}$} \\
\hline & & $\beta^{C A}$ & $t$ & $\beta^{U S}$ & $t$ & $\delta$ & $t$ & $\gamma$ & $t$ & & & TFI & $t$ \\
\hline \multicolumn{14}{|c|}{ Industry Level, OLS } \\
\hline 1 & gdp, rer (2) & .15 & 3.11 & .04 & 1.14 & .25 & 8.30 & .16 & 1.99 & .31 & & .058 & 3.79 \\
\hline 2 & gdp, rer (0) & .15 & 2.77 & .02 & 0.40 & .13 & 1.79 & .28 & 3.05 & .09 & & .050 & 2.87 \\
\hline 3 & $g d p(2)$ & .17 & 3.21 & .04 & 1.17 & .25 & 5.19 & .21 & 2.43 & .18 & & .065 & 3.87 \\
\hline $4^{b}$ & -- & .16 & 2.85 & .01 & 0.34 & & & .29 & 3.23 & .08 & & .051 & 2.89 \\
\hline $5^{b}$ & & .14 & 2.79 & .05 & 1.36 & .26 & 8.77 & .05 & 0.31 & .29 & & .058 & 2.46 \\
\hline & gdp, rer (2) & .14 & 2.96 & .05 & 1.44 & .27 & 8.82 & & & .30 & & .059 & 3.89 \\
\hline $7^{b}$ & -- & .15 & 2.58 & .03 & 0.76 & & & & & .04 & & .053 & 2.98 \\
\hline $8^{b}$ & gdp, rer (2) & .17 & 2.97 & .04 & 0.98 & .26 & 8.34 & .16 & 1.95 & .30 & & .061 & 3.76 \\
\hline $9^{b}$ & gdp, rer (2) & .16 & 3.27 & .02 & 0.49 & .26 & 8.61 & .18 & 2.24 & .33 & & .051 & 3.36 \\
\hline \multicolumn{14}{|c|}{ Plant Level, OLS } \\
\hline & gdp, rer (2) & .08 & 1.70 & .14 & 3.97 & .12 & 3.95 & .11 & 1.51 & .06 & & .074 & 4.92 \\
\hline & gdp, rer (2) & .09 & 1.92 & .11 & 3.02 & .10 & 3.18 & .14 & 1.79 & .01 & & .066 & 4.39 \\
\hline \multicolumn{14}{|c|}{ Industry Level, IV } \\
\hline & gdp, rer (2) & .15 & 1.10 & .10 & 0.86 & .26 & 8.09 & .14 & 1.53 & .30 & $.86 / .43$ & .081 & 3.41 \\
\hline & gdp, rer (2) & .13 & 0.89 & .13 & 1.01 & .28 & 6.99 & -.08 & -0.28 & .28 & .87 / .51 & .083 & 3.40 \\
\hline \multicolumn{14}{|c|}{ Plant Level, IV } \\
\hline & gdp, rer (2) & .22 & 1.67 & .05 & 0.49 & .11 & 3.20 & .17 & 1.80 & .06 & $.06 / .77$ & .082 & 2.53 \\
\hline $15^{b}$ & gdp, rer (2) & .79 & 2.58 & -.49 & -1.73 & -.19 & -1.29 & 2.07 & 2.29 & .05 & $.76 / .52$ & .050 & 0.39 \\
\hline
\end{tabular}

Notes:

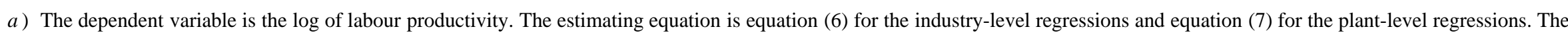
number of observations is 211 for the industry-level regressions and 3,726 for the plant-level regressions. See the notes to table 1 for additional details.

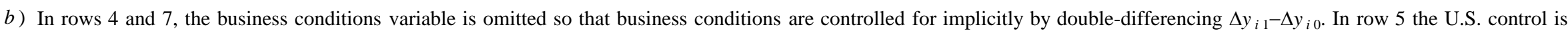
replaced by the Japan-U.K. control discussed in the text. In row 8, the 2 'outlier' observations with the largest Canadian tariff cuts are omitted. In row 9 , all 9 observations associated with the automotive sector are omitted. In row 11, the plant controls are omitted. In rows 12 and 14, only the Canadian and U.S. tariff variables are endogenized. In rows 13 and 15 , the two tariff variables and the U.S. control are endogenized. 
Table 3. Trade Diversion/Creation, Import Prices, and Output

\begin{tabular}{|c|c|c|c|c|c|c|c|c|c|c|}
\hline \multirow[b]{2}{*}{ Variable } & \multicolumn{2}{|c|}{$\begin{array}{c}\text { Canadian } \\
\text { Tariffs }\end{array}$} & \multicolumn{2}{|c|}{$\begin{array}{l}\text { U.S. } \\
\text { Tariffs }\end{array}$} & \multicolumn{2}{|c|}{$\begin{array}{c}\text { Total FTA } \\
\text { Impact }\end{array}$} & \multirow{2}{*}{$\begin{array}{c}\begin{array}{c}\text { Business } \\
\text { Conditions }\end{array} \\
\delta \\
\end{array}$} & \multirow{2}{*}{$\begin{array}{r}\text { Adj. } \\
R^{2}\end{array}$} & \multirow{2}{*}{$\begin{array}{c}\text { OverId / } \\
\text { Hausman }^{d} \\
\end{array}$} & \multirow{2}{*}{$\begin{array}{r}\text { Observa- } \\
\text { tions } \\
\end{array}$} \\
\hline & $\beta^{C A}$ & $t$ & $\beta^{U S}$ & $t$ & TFI & $t$ & & & & \\
\hline \multicolumn{11}{|c|}{ Canadian Imports from the U.S. } \\
\hline OLS Industry & .54 & -4.67 & .16 & -2.16 & .01 & .83 & $.22 *^{c}$ & .24 & & 211 \\
\hline IV Industry & 2.32 & .80 & -.86 & -.40 & -.15 & -.48 & .30 & .15 & $\mathrm{NA} / .28$ & 211 \\
\hline \multicolumn{11}{|c|}{ Canadian Imports from the Rest of the World } \\
\hline OLS Industry & -.40 & 2.67 & .08 & -.17 & .03 & .12 & $.11 *$ & .05 & & 211 \\
\hline IV Industry & -1.60 & -.54 & 1.24 & .48 & .22 & .47 & .08 & .04 & NA / .75 & 211 \\
\hline \multicolumn{11}{|c|}{ Canadian Import Prices } \\
\hline OLS Product & -.004 & .20 & & & & & & .00 & & 4,700 \\
\hline IV Product & -.073 & 2.26 & & & & & & .00 & $.51 / .03$ & 4,700 \\
\hline \multicolumn{11}{|c|}{ Canadian Import Quantities } \\
\hline OLS Product & .70 & 15.12 & & & & & & .05 & & 4,700 \\
\hline IV Product & 1.02 & 12.68 & & & & & & .04 & $.87 / .00$ & 4,700 \\
\hline \multicolumn{11}{|c|}{ Gross Output Per Plant in Production Activities } \\
\hline OLS Industry & -.05 & -.65 & .03 & .54 & .00 & -.05 & $.30 *$ & .18 & & 211 \\
\hline IV Plant & -.05 & -1.36 & .06 & 2.01 & .01 & .72 & $.16 *$ & .05 & & 3,751 \\
\hline
\end{tabular}

Notes :

a) The dependent variable is indicated in bold font at the start of each block of results e.g., 'Canadian Imports from the U.S.' All dependent variables are in logs. The estimating equation is equation (6) for the industry-level regressions, equation (7) for the plant-level regressions, and equation (10) for the product-level regressions. The business conditions variable is the same as in the table 1, row 1 baseline specification. The U.S. control is not included either because it is inappropriate (the trade equations) or because the published data on the number of plants are only available at 5-year intervals (the output per plant equations).

b) $\beta^{C A}$ and $\beta^{U S}$ are scaled as described in the notes to table 1 .

c) An asterisk indicates statistical significance at the 1 percent level.

d) The 'OverId/Hausman' column reports $p$-values for the over-identification and Hausman tests. Rejection of the instrument set or exogeneity are indicated by $p$-values of less than 0.01 . Blank entries indicate OLS estimation. The instrument set varies across specifications according to results of the over-identification tests. The industry-level import results use wages and employment and so are just identified (NA). The product-level import results use wages, employment, squares, and cross. products. The output results use wages, employment, imports, exports, squares, and cross-products. 
Table 4. Employment and Skill Upgrading

\begin{tabular}{|c|c|c|c|c|c|c|c|c|c|c|}
\hline \multirow[b]{2}{*}{ Variable } & \multicolumn{2}{|c|}{$\begin{array}{c}\text { Canadian } \\
\text { Tariffs }\end{array}$} & \multicolumn{2}{|c|}{$\begin{array}{l}\text { U.S. } \\
\text { Tariffs }\end{array}$} & \multicolumn{2}{|c|}{$\begin{array}{c}\text { Total FTA } \\
\text { Impact }\end{array}$} & \multirow{2}{*}{$\begin{array}{c}\begin{array}{c}\text { Business } \\
\text { Conditions }\end{array} \\
\delta \\
\end{array}$} & \multirow{2}{*}{$\begin{array}{c}\text { U.S. } \\
\text { Control } \\
\gamma \\
\end{array}$} & \multirow{2}{*}{$\begin{array}{r}\text { Adj. } \\
R^{2}\end{array}$} & \multirow{2}{*}{$\begin{array}{l}\text { OverId / } \\
\text { Hausman }\end{array}$} \\
\hline & $\beta^{C A}$ & $t$ & $\beta^{U S}$ & $t$ & TFI & $t$ & & & & \\
\hline \multicolumn{11}{|c|}{ Employment - Production Workers } \\
\hline 1 Industry & -.14 & -2.44 & -.07 & -1.56 & -.08 & -3.44 & $.37 *^{b}$ & .16 & .33 & \\
\hline 5 Industry & -.13 & -1.99 & -.07 & -1.36 & -.08 & -2.89 & & .21 & .07 & \\
\hline 6 Industry & -.16 & -2.93 & -.08 & -1.71 & -.09 & -4.08 & $.37 *$ & & .32 & \\
\hline 12 Industry & -.20 & -1.28 & .03 & .17 & -.06 & -1.60 & $.37 *$ & .16 & .32 & .62 / .99 \\
\hline 10 Plant & -.09 & -2.58 & -.03 & -.87 & -.04 & -3.01 & $.17 *$ & $.29 *^{b}$ & .04 & \\
\hline \multicolumn{11}{|c|}{ Employment - Non-Production Workers } \\
\hline 1 Industry & -.06 & -.71 & .05 & .79 & .00 & .02 & $.36 *$ & .07 & .26 & \\
\hline 5 Industry & -.07 & -.77 & .05 & .73 & .00 & -.09 & & .14 & .00 & \\
\hline 6 Industry & -.06 & -.79 & .04 & 71 & .00 & -.12 & $.36 *$ & & .26 & \\
\hline 12 Industry & .01 & .06 & .11 & .52 & .05 & 1.22 & $.36 *$ & .11 & .25 & .19 / .85 \\
\hline 10 Plant & -.14 & -3.02 & .04 & 1.19 & -.03 & -1.72 & .02 & .15 & .01 & \\
\hline \multicolumn{11}{|c|}{ Skill Upgrading $^{c}$} \\
\hline 1 Industry & .11 & 1.41 & .10 & 1.67 & .08 & 2.72 & $.47 *$ & .24 & .48 & \\
\hline 5 Industry & .08 & .79 & .11 & 1.26 & .07 & 1.81 & & .24 & .01 & \\
\hline 6 Industry & .12 & 1.63 & .10 & 1.56 & .08 & 2.82 & $.47 *$ & & .48 & \\
\hline 12 Industry & .11 & .50 & 15 & .74 & .10 & 2.21 & $.47 *$ & .25 & .48 & $.12 / .99$ \\
\hline 10 Plant & -.01 & -.30 & .04 & 1.48 & .01 & .96 & $.05 *$ & .17 & .01 & \\
\hline
\end{tabular}

Notes :

a) The dependent variable is indicated in bold font at the start of each block of results e.g., 'Employment - Production Workers.' The estimating equation is equation (6) for the industry-level regressions and equation (7) for the plant-level regressions. Row numbers correspond to those in table 1 so that the reader can refer to table 1 for details of the specification. Rows 1 and 10 are my baseline specifications. See notes to table 1 for further details, including the scaling of the $\beta^{C A}$ and $\beta^{U S}$.

b) An asterisk indicates statistical significance at the 1 percent level.

c) Skill upgrading is the log of the ratio of non-production workers to production workers.

d) All dependent variables are in logs. The number of observations in the industry-level (plant-level) regressions is $211(3,742)$ for production workers, $212(3,539)$ for non-production workers, and $211(3,489)$ for skill upgrading. 
Table 5. Earnings, Wages, Hours, and Inequality

\begin{tabular}{|c|c|c|c|c|c|c|c|c|c|}
\hline \multirow[b]{2}{*}{ Variable } & \multicolumn{2}{|c|}{$\begin{array}{c}\text { Canadian } \\
\text { Tariffs }\end{array}$} & \multicolumn{2}{|c|}{$\begin{array}{l}\text { U.S. } \\
\text { Tariffs }\end{array}$} & \multicolumn{2}{|c|}{$\begin{array}{l}\text { Total FTA } \\
\text { Impact }\end{array}$} & \multirow{2}{*}{$\begin{array}{c}\begin{array}{c}\text { Business } \\
\text { Conditions }\end{array} \\
\delta\end{array}$} & \multirow{2}{*}{$\begin{array}{c}\text { U.S. } \\
\text { Control } \\
\gamma\end{array}$} & \multirow{2}{*}{$\begin{array}{r}\text { Adj. } \\
R^{2}\end{array}$} \\
\hline & $\beta^{C A}$ & $t$ & $\beta^{U S}$ & $t$ & TFI & $t$ & & & \\
\hline \multicolumn{10}{|c|}{ Earnings - All Workers } \\
\hline 1 Industry & .05 & 2.43 & .03 & 1.92 & .03 & 3.80 & $.34 *^{b}$ & $.25 *^{b}$ & .20 \\
\hline 10 Plant & .04 & 2.92 & .04 & 3.60 & .03 & 5.64 & $.17 *$ & $.19 *$ & .03 \\
\hline \multicolumn{10}{|c|}{ Earnings - Production Workers } \\
\hline 1 Industry & .04 & 2.12 & .00 & -.02 & .02 & 3.61 & $.16 *$ & .11 & .07 \\
\hline 10 Plant & .05 & 3.25 & .03 & 2.57 & .03 & 4.74 & .12 & .21 & .02 \\
\hline \multicolumn{10}{|c|}{ Earnings - Non-Production Workers } \\
\hline 1 Industry & .01 & .30 & -.01 & -.29 & .00 & .02 & $.18 *$ & .12 & .08 \\
\hline 10 Plant & .04 & 1.48 & .06 & 2.87 & .03 & 3.67 & .11 & .11 & .01 \\
\hline \multicolumn{10}{|c|}{ Hourly Wages of Production Workers } \\
\hline 1 Industry & .05 & 3.15 & .03 & 1.84 & .03 & 4.37 & $.60 *$ & .13 & .33 \\
\hline 10 Plant & .06 & 3.23 & .02 & 1.40 & .03 & 4.04 & .20 & $.16 *$ & .01 \\
\hline \multicolumn{10}{|c|}{ Annual Hours of Production Workers } \\
\hline 1 Industry & -.01 & -.48 & -.02 & -1.75 & -.01 & -1.94 & .02 & .14 & .01 \\
\hline 10 Plant & -.02 & -.90 & .01 & .80 & .00 & -.12 & .03 & .07 & .00 \\
\hline \multicolumn{10}{|c|}{ Earnings Inequality ${ }^{c}$} \\
\hline 1 Industry & -.04 & -1.32 & -.01 & -.55 & -.02 & -1.66 & $.42 *$ & .05 & .21 \\
\hline 10 Plant & -.01 & -.46 & .02 & .97 & .00 & .41 & $.13 *$ & .08 & .00 \\
\hline
\end{tabular}

Notes:

a) The dependent variable is indicated in bold font at the start of each block of results e.g., 'Earnings - All Workers.' The estimating equation is equation (6) for the industry-level regressions and equation (7) for the plant-level regressions. Row numbers correspond to those in table 1 so that the reader can refer to table 1 for details of the specification. Rows 1 and 10 are my baseline specifications. See notes to table 1 for further details, including the scaling of the $\beta^{C A}$ and $\beta^{U S}$.

b) An asterisk indicates statistical significance at the 1 percent level.

c) Earnings inequality is the ratio of non-production-worker earnings to production-workers earnings.

d) All dependent variables are in logs. The number of observations in the industry-level (plant-level) regressions is $213(3,801)$ for the earnings of all workers, $211(3,742)$ for the earnings of production workers, $212(3,526)$ for the earnings of non-production workers, $211(3,489)$ for earnings inequality, $211(3,738)$ for wages, and $211(3,738)$ for hours. 
Table A1. The 71 Most-Impacted, Import-Competing Industries

\begin{tabular}{|c|c|c|c|c|c|c|c|}
\hline SIC & INDUSTRY DESCRIPTION & $\Delta \tau_{i 1}{ }^{C A}$ & $\Delta \tau_{i 1}{ }^{U S}$ & SIC & INDUSTRY DESCRIPTION & $\Delta \tau_{i 1}{ }^{C A}$ & $\Delta \tau_{i 1}{ }^{U S}$ \\
\hline 1131 & Brewery Products Industry & -.331 & -.012 & $\overline{3612}$ & Lubricating Oil And Grease Industry & -.079 & -.004 \\
\hline 3271 & Shipbuilding And Repair Industry & -.241 & -.012 & 2641 & Metal Office Furniture Industry & -.079 & -.001 \\
\hline 1931 & Canvas And Related Products Industry & -.183 & -.008 & 2811 & Business Forms Printing Industry & -.078 & -.016 \\
\hline 2433 & Men's and Boy's Pants Industry & -.170 & $-.053 *$ & 1921 & Carpet, Mat And Rug Industry & -.078 & -.021 \\
\hline 2443 & Women's Dress Industry & -.162 & $-.076 *$ & 1083 & Sugar And Chocolate Confectionery Industry & -.077 & -.024 \\
\hline 2491 & Sweater Industry & -.159 & $-.125 *$ & 3751 & Paint And Varnish Industry & -.073 & $-.036 *$ \\
\hline 2451 & Children's Clothing Industry & -.159 & $-.031 *$ & 2542 & Wooden Kitchen Cabinet And Bathroom Vanity Ind. & -.073 & -.002 \\
\hline 2441 & Women's Coat and Jacket Industry & -.157 & $-.049 *$ & 1141 & Wine Industry & -.071 & $-.030 *$ \\
\hline 1993 & Household Products Of Textile Materials & -.156 & -.017 & 3771 & Toilet Preparations Industry & -.070 & -.024 \\
\hline 2442 & Women's Sportswear Industry & -.154 & $-.053 *$ & 3993 & Floor Tile, Linoleum And Coated Fabrics Inds. & -.070 & $-.045 *$ \\
\hline 2494 & Hosiery Industry & -.152 & $-.040 *$ & 2721 & Asphalt Roofing Industry & -.069 & $-.044 *$ \\
\hline 1911 & Natural Fibres Processing And Felt Processing & -.150 & $-.041 *$ & 3791 & Printing Ink Industry & -.069 & -.017 \\
\hline 2434 & Men's and Boy's Shirt and Underwear Industry & -.147 & $-.072 *$ & 2492 & Occupational Clothing Industry & -.066 & $-.031 *$ \\
\hline 2432 & Men's and Boy's Suit and Jacket Industry & -.147 & $-.065 *$ & 3542 & Structural Concrete Products Industry & -.066 & -.015 \\
\hline 2431 & Men's and Boy's Coat Industry & -.143 & $-.079 *$ & 3021 & Metal Tanks (Heavy Gauge) Industry & -.066 & -.011 \\
\hline 2493 & Glove Industry & -.140 & -.020 & 3029 & Other Fabricated Structural Metal Products Inds. & -.065 & $-.033 *$ \\
\hline 2496 & Foundation Garment Industry & -.137 & $-.029 *$ & 3931 & Sporting Goods Industry & -.065 & -.010 \\
\hline 1712 & Footwear Industry & -.127 & $-.082 *$ & 1821 & Wool Yarn And Woven Cloth Industry & -.061 & .004 \\
\hline 2612 & Upholstered Household Furniture Industry & -.112 & -.001 & 2733 & Paper Bag Industry & -.061 & $-.042 *$ \\
\hline 1998 & Tire Cord Fabric Industry \& Other Textiles Products & -.108 & $-.047 *$ & 3243 & Non-Commercial Trailer Industry & -.060 & .009 \\
\hline 2611 & Wooden Household Furniture Industry & -.106 & -.002 & 1621 & Plastic Pipe And Pipe Fittings Industry & -.058 & $-.031 *$ \\
\hline 2499 & Other Clothing And Apparel Industries & -.103 & $-.040 *$ & 3311 & Small Electrical Appliance Industry & -.058 & -.024 \\
\hline 2581 & Coffin And Casket Industry & -.101 & -.004 & 1051 & Cereal Grain Flour Industry & -.057 & -.008 \\
\hline 2495 & Fur Goods Industry & -.097 & $-.053 *$ & 3032 & Prefabricated Portable Metal Buildings Industry & -.057 & .000 \\
\hline 2444 & Women's Blouse and Shirt Industry & -.094 & $-.104 *$ & 2941 & Iron Foundries & -.057 & -.002 \\
\hline 2649 & Other Office Furniture Industries & -.090 & -.002 & 1093 & Potato Chip, Pretzel And Popcorn Industry & -.056 & .017 \\
\hline 1041 & Fluid Milk Industry & -.089 & -.006 & 3991 & Broom, Brush And Mop Industry & -.055 & $-.040 *$ \\
\hline 1991 & Narrow Fabric Industry & -.089 & -.002 & 2792 & Stationery Paper Products Industry & -.054 & -.013 \\
\hline 2619 & Other Household Furniture Industries & -.089 & -.012 & 1052 & Prepared Flour Mixes And Prepared Cereal Foods & -.054 & -.021 \\
\hline 3761 & Soap And Cleaning Compounds Industry & -.088 & $-.032 *$ & 2819 & Other Commercial Printing Industries & -.052 & -.003 \\
\hline 1829 & Other Spun Yarn And Woven Cloth Industries & -.088 & $-.081 *$ & 2799 & Other Converted Paper Products Industries & -.051 & -.013 \\
\hline 3242 & Commercial Trailer Industry & -.087 & -.004 & 3031 & Metal Door And Window Industry & -.051 & $-.032 *$ \\
\hline 3792 & Adhesives Industry & -.084 & $-.025 *$ & 2821 & Platemaking Typesetting And Bindery Industry & -.051 & -.012 \\
\hline 1713 & Luggage, Purse And Handbag Industry & -.082 & $-.073 *$ & 1012 & Poutry Products Industry & -.051 & -.017 \\
\hline 2543 & Wooden Door And Window Industry & -.079 & $-.039 *$ & 3594 & Non-Metallic Mineral Insulating Materials Inds. & -.049 & $-.058 *$ \\
\hline 1691 & Plastic Bag Industry & -.079 & -.023 & & & & \\
\hline
\end{tabular}

Notes: This table reports 1988-96 changes in tariff concessions for those industries in the most-impacted, import-competing group. An asterisk indicates that the industry is also in the most-impacted, export-oriented group of industries. 
Table A2. Different Choices of pre-FTA and FTA Periods

\begin{tabular}{|c|c|c|c|c|}
\hline \multirow[b]{2}{*}{ Variable } & \multicolumn{2}{|c|}{$\begin{array}{c}\text { Canadian } \\
\text { Tariffs } \Delta \tau^{C A}\end{array}$} & \multicolumn{2}{|c|}{$\begin{array}{c}\text { U.S. Tariffs } \\
\qquad \Delta \tau^{U S}\end{array}$} \\
\hline & $\beta^{C A}$ & $t$ & $\beta^{U S}$ & $t$ \\
\hline \multicolumn{5}{|l|}{ Employment, OLS } \\
\hline 1980-86, 1988-96 & -0.12 & -2.35 & -0.03 & -0.67 \\
\hline 1980-88, 1988-96 & -0.09 & -2.03 & 0.00 & 0.04 \\
\hline 1980-86, 1988-94 & -0.13 & -2.35 & 0.00 & 0.02 \\
\hline 1981-88, 1989-96 & -0.10 & -2.05 & 0.01 & 0.14 \\
\hline \multicolumn{5}{|l|}{ Productivity, OLS } \\
\hline 1980-86, 1988-96 & 0.15 & 3.11 & 0.04 & 1.14 \\
\hline 1980-88, 1988-96 & 0.15 & 3.35 & 0.00 & 0.04 \\
\hline 1980-86, 1988-94 & 0.17 & 2.74 & 0.01 & 0.20 \\
\hline 1981-88, 1989-96 & 0.12 & 2.64 & -0.04 & -1.03 \\
\hline
\end{tabular}

a) The dependent variable is given in bold. The estimating equation is equation (6). All rows correspond to the table 1, row 1 baseline specification except in the choice of years used for the difference of differences. 
Table A3. Sensitivity to Different Definitions of Labour Productivity

\begin{tabular}{|c|c|c|c|c|c|c|c|c|c|}
\hline & \multicolumn{2}{|c|}{$\begin{array}{c}\text { Canadian } \\
\text { Tariffs } \\
\end{array}$} & \multicolumn{2}{|c|}{$\begin{array}{l}\text { U.S. } \\
\text { Tariffs }\end{array}$} & \multicolumn{2}{|c|}{$\begin{array}{c}\text { Total FTA } \\
\text { Impact } \\
\end{array}$} & \multirow{2}{*}{$\begin{array}{c}\begin{array}{c}\text { Business } \\
\text { Conditions }\end{array} \\
\delta \\
\end{array}$} & \multirow{2}{*}{$\begin{array}{c}\text { U.S. } \\
\text { Control } \\
\gamma\end{array}$} & \multirow{2}{*}{$\begin{array}{r}\text { Adj } \\
R^{2} \\
\end{array}$} \\
\hline & $\beta^{C A}$ & $t$ & $\beta^{U S}$ & $t$ & TFI & $t$ & & & \\
\hline \multicolumn{10}{|c|}{ 1. Labour Productivity - Production Activities - Hours Adjusted - Output Deflators } \\
\hline 1 Industry & .15 & 3.11 & .04 & 1.14 & .06 & 3.79 & $.25 *^{b}$ & .16 & .31 \\
\hline 10 Plant & .08 & 1.70 & .14 & 3.97 & .07 & 4.92 & $.12 *$ & .00 & .06 \\
\hline \multicolumn{10}{|c|}{ 2. Labour Productivity - Production Activities - Hours Adjusted - Value-Added Deflators } \\
\hline 1 Industry & .17 & 2.96 & .03 & .67 & .06 & 3.26 & $.19 *$ & .13 & .16 \\
\hline 10 Plant & .10 & 2.06 & .16 & 4.58 & .09 & 5.69 & .07 & $.20 *^{b}$ & .07 \\
\hline \multicolumn{10}{|c|}{ 3. Labour Productivity - All Activities - Not Hours Adjusted - Output Deflators } \\
\hline 1 Industry & .11 & 2.27 & -.03 & -.93 & .02 & 1.29 & $.20 *$ & $.24 *$ & .19 \\
\hline 10 Plant & .09 & 2.19 & .13 & 4.07 & .07 & 5.54 & $.11 *$ & .13 & .09 \\
\hline
\end{tabular}

Notes:

a) The dependent variable is indicated in bold font at the start of each block of results. The estimating equation is equation (6) for the industry-level regressions and equation (7) for the plant-level regressions. Rows 1 and 10 are my baseline specifications as in table 1 . See the notes to table 1 for further details, including the scaling of the $\beta^{C A}$ and $\beta^{U S}$. All estimates are OLS.

b) An asterisk indicates statistical significance at the 1 percent level.

c) All dependent variables are in logs. The number of observations in the industry-level (plant-level) regressions is $211(3,726)$ for measures 1 and 2 and $213(3,801)$ for measure 3. 